Report No. BMI-1252

UC-47 Technology - Feed Materials

(TID-4500, 13th Ed., Suppl.)

Contract No. W-7405-eng-92

THE CORROSION OF TYPE 347 STAINLESS

STEEL IN BOILING DIGEST LIQUORS

by

Frederick W. Fink

Walter J. Braun

Oliver M. Stewart

January 28, 1958

BATTELLE MEMORIAL INSTITUTE

505 King Avenue

Columbus 1, Ohio 


\section{DISCLAIMER}

This report was prepared as an account of work sponsored by an agency of the United States Government. Neither the United States Government nor any agency Thereof, nor any of their employees, makes any warranty, express or implied, or assumes any legal liability or responsibility for the accuracy, completeness, or usefulness of any information, apparatus, product, or process disclosed, or represents that its use would not infringe privately owned rights. Reference herein to any specific commercial product, process, or service by trade name, trademark, manufacturer, or otherwise does not necessarily constitute or imply its endorsement, recommendation, or favoring by the United States Government or any agency thereof. The views and opinions of authors expressed herein do not necessarily state or reflect those of the United States Government or any agency thereof. 


\section{DISCLAIMER}

Portions of this document may be illegible in electronic image products. Images are produced from the best available original document. 


\section{TABLE OF CONTENTS}

\section{$\underline{\text { Page }}$}

ABSTRACT

INTRODUCTION

EXPERIMENTAL PROCEDURES

Reflux-Type Corrosion-Test Units

Preparation of Specimens

Exposure of Specimens

Chemical Composition of Digest Liquor.

Reference Digest Liquors

EXPERIMENTAL RESULTS

Effect of Varying Nitric Acid and Uranium Contents . . . . . . . . 6

Effect of Minor Constituents From the Feed . . . . . . . . . . 8

Effect of Aluminum on Corrosion by Fluoride . . . . . . . . . . 12

Effect of Iron on Corrosion by Chloride . . . . . . . . . . . . 16

Resistance of Other Stainless Alloys to Digest Liquors Containing

Fluoride Ion . . . . . . . . . . . . . . . . . . . . 20

Digest Liquors From More Recent Production . . . . . . . . . 20

REFERENCES . . . . . . . . . . . . . . . . . . . . . . . . 25

APPENDIX

ADDITIONAL CORROSION DATA . . . . . . . . . . . . . . . . . 


\title{
THE CORROSION OF TYPE 347 STAINLESS STEEL IN BOILING DIGEST LIQUORS
}

\author{
Frederick W. Fink, Walter J. Braun, \\ and Oliver M. Stewart
}

\begin{abstract}
Corrosion studies indicate that digest liquors presently in use at the Mallinckrodt Uranium Refining Center should not be excessively corrosive to the digesters, which are constructed of Type 347 stainless steel. Experimental tests have shown that the digest liquors resulting from some of the more recent sources of uranium concentrates might become corrosive if the fluoride, chloride, or free nitric acid contents of these liquors should reach abnormal levels. If such constituents are present, there are corrective procedures that may be employed to prevent excessive corrosion of the stainless steel. It has been demonstrated that aluminum additions to the digest liquors will reduce the attack in both the liquid and vapor phases when relatively high concentrations of fluoride are involved. Iron additions may be used to some extent to combat corrosion arising from high chloride levels. Type 304 ELC stainless steel appears to have comparable corrosion resistance to Type 347 and Carpenter No. 20 stainless. Haynes Alloy No. 25, which showed a somewhat lower rate of penetration, tended to form a loose insoluble corrosion product which may be objectionable in service.
\end{abstract}

\section{INTRODUCTION}

Uranium concentrates are digested in a nitric acid solution at an early step in the refining process employed by the Mallinckrodt Uranium Refining Center. The resultant acid solution is known as digest liquor. Many other elements, in addition to uranium, are dissolved from the feed material by this process of digestion. Presently, digestion is carried out in vessels constructed of Type 347 stainless steel.

Pitting and local attack on weldments have been observed in the plant. It was suspected that the corrosiveness of the digest liquors varied with variations in the contaminants of the feed materials, and with the amount of free nitric acid present in the liquor.

Particular concern has arisen over the possibility that some of the uranium raw materials from newer sources, which are now being refined, might result in digest liquors much more corrosive than any which have been processed previously.

An experimental evaluation of the effects of variations in the composition of the feed, and in the concentration of free nitric acid, on the corrosion of Type 347 stainless steel was needed in order to establish the factors which would lead to improved service life of digester equipment. The research described in this report was designed to indicate which contaminants in the feed materials might be expected to lead to increased corrosion, and how this attack might best be controlled. The authors much appreciated the assistance of G. L. Ericson and C. L. Peterson of Battelle in their review of the report. 
EXPERIMENTAL PROCEDURES

Reflux-Type Corrosion-Test Units

Pyrex reflux units were used to evaluate the factors involved in the corrosion of Type 347 stainless steel in contact with boiling digest liquors. In the special cases where a high fluoride concentration was present in the solution, special reflux units constructed from Teflon were employed.

\section{Preparation of Specimens}

Specimens for the corrosion tests were cut and machined to 1 by 2 -in. dimensions from 11-gage (0.125 in.) Type 347 stainless steel sheet. Specimens of corresponding size and shape, but containing a butt-welded joint, were fabricated by welding together two 1 by 36 -in. strips of this sheet steel, and then cutting and machining to the above size. Either conventional arc welding, using specified coated electrodes for Type 347 stainless steel, or the Heliarc process, in which uncoated Type 347 stainless steel electrodes were melted by an argon-shielded tungsten arc, was used in the welding operation.

All specimens were given a pickling treatment prior to exposure to remove weld scale and traces of foreign matter. This treatment was designed to produce a surface condition which was uniform for all samples.

Two pre-exposure cleaning treatments were used. Specimens which were to be exposed to solutions composed of uranium and free nitric acid were pickled.at $140 \mathrm{~F}$ in a bath containing 45 volume per cent nitric acid and 10 volume per cent hydrofluoric acid. Pickling was continued until the loosened scale could be removed easily by brushing. Specimens scheduled for exposure in digest-liquor solutions plus added contaminant ions were descaled in a molten bath of Virgo Descaling Salt (an inhibited causticbase bath manufactured by the Hooker Electrochemical Company) for $15 \mathrm{~min}$. Loose scale was then removed by a 2 -min dip in 10 volume per cent reagent-grade sulfuric acid at $180 \mathrm{~F}$, followed by brushing. All specimens were given a 2 -min passivation treatment at $150 \mathrm{~F}$ in 10 volume per cent reagent-grade nitric acid, and then desiccated at least $24 \mathrm{hr}$ prior to exposure. Immediately before exposure, all samples were degreased in acetone and weighed.

\section{Exposure of Specimens}

Pairs consisting of both a welded and an unwelded specimen were included in each exposure position. The usual practice was to expose one pair in the vapor phase, one pair at the interface, and one pair in the liquid phase.

The solution was replaced at the end of alternate 96-hr exposure periods. After exposure the specimens were rinsed with water, dried in an oven at $140 \mathrm{~F}$, and 
weighed. The corrosion rate was calculated as mils per month penetration from the weight loss. Each sample was studied at $20 \mathrm{X}$ magnification to determine the extent of pitting or localized attack.

\section{Chemical Composition of Digest Liquor}

The analysis of a 55-gal sample of digest liquor received from the Mallinckrodt Uranium Refining Center in August, 1951, is shown in Table 1. This analysis includes the concentrations of uranium, other cations, free nitric acid, and anions frequently associated with corrosion such as fluoride, chloride, and sulfate.

TABLE 1. COMPOSITIONS OF THE DIGEST LIQUOR RECEIVED FROM MALLINCKRODT URANIUM REFINING CENTER IN AUGUST, 1951 , AND THE REFERENCE LIQUORS

\begin{tabular}{|c|c|c|c|c|c|}
\hline \multirow[b]{3}{*}{ Constituent } & \multicolumn{5}{|c|}{ Concentration, g per liter } \\
\hline & \multirow{2}{*}{$\begin{array}{l}\text { Analysis of } \\
\text { Digest } \\
\text { Liquor } \\
\text { As Received }\end{array}$} & \multicolumn{2}{|c|}{ Reference 80 Liquor } & \multicolumn{2}{|c|}{ Reference 250 Liquor } \\
\hline & & $\begin{array}{l}\text { Calculated }(a) \\
\text { Composition }\end{array}$ & $\begin{array}{l}\text { Analysis } \\
\text { After } \\
\text { Dilution }\end{array}$ & $\begin{array}{l}\text { Calculated }(a) \\
\text { Composition }\end{array}$ & $\begin{array}{c}\text { Analysis } \\
\text { After } \\
\text { Concentration }\end{array}$ \\
\hline Uranium & 157. & 80. & 80. & 250 & 250 \\
\hline Free nitric acid & 22.8 & 378. & 385. & 63.0 & 58.7 \\
\hline Total nitrate & 210 & 478. & 459. & 378. & 372. \\
\hline Sulfate & 36.0 & 18.3 & 17.4 & 57.3 & 50.3 \\
\hline Phosphate & 1.44 & 0.73 & 0.80 & 2.3 & 2.3 \\
\hline Fluoride & 0.19 & 0.097 & 0.09 & 0.30 & 0.27 \\
\hline Chloride & 0.11 & 0.056 & 0.042 & 0.175 & 0.044 \\
\hline Arsenate & 0.017 & 0.009 & 0.004 & 0.027 & 0.02 \\
\hline Aluminum & 3.80 & 1.94 & 1.91 & 5.68 & 5.60 \\
\hline Iron & 2.77 & 1.41 & -- & 4. 40 & -- \\
\hline Nickel & 10.4 & 5.3 & -- & 16.6 & -- \\
\hline Cobalt & 7.26 & 3.70 & -- & 11.6 & -- \\
\hline Copper & 1.66 & 0.85 & -- & 2.64 & -- \\
\hline Molybdenum & 0.73 & 0.37 & -- & 1. 16 & -- \\
\hline Vanadium & 0.40 & 0.20 & -- & 0.64 & - - \\
\hline Manganese & 0.15 & 0.076 & -- & 0.24 & -- \\
\hline
\end{tabular}

(a) Calculated from the as-received analysis. 
$\underline{\text { Reference Digest Liquors }}$

Composition

The digestion process commences with a liquor which is low in uranium and high in free nitric acid content. As digestion proceeds, the concentration of dissolved uranium and other acid-soluble constituents increases greatly while most of the free nitric acid is consumed. For the purposes of this study, two reference digest-liquor compositions were chosen to represent early and late stages in the digestion process. These liquors were made up with the following compositions:

(1) $6 \mathrm{~N}$ nitric acid, $80 \mathrm{~g}$ uranium per liter (representing an early stage in the refining process)

(2) $1 \mathrm{~N}$ nitric acid, $250 \mathrm{~g}$ uranium per liter (representing a late stage in the refining process).

These liquors are designated as the Reference 80 and Reference 250 digest liquors, respectively, hereinafter in this report.

\section{Preparation}

The two reference liquors were prepared directly by dilution or concentration techniques from the digest liquor provided by the Mallinckrodt refinery in August, 1951. In Table 1, the compositions of the Reference 80 and Reference 250 liquors, calculated from the analyzed composition of the as-received digest liquor, are compared with the compositions actually found by analysis. A comparison of the calculated and analyzed results show that none of the concentrations of the various constituents was seriously altered by the manipulations involved in producing the reference liquors.

\section{Stability}

Both reference liquors were refluxed in contact with Type 347 stainless steel specimens to see if such exposure would significantly alter the concentration of those contaminating ions which are important from the corrosion standpoint. Analyses were made after boiling had continued for 16, 42, 96, and $192 \mathrm{hr}$ (see Table 2). In general the compositions of the reference liquors remained unchanged. A slight decrease in the concentrations of chloride and fluoride occurred on boiling for $192 \mathrm{hr}$. However, these relatively small losses were not considered significant.

\section{EXPERIMENTAL RESULTS}

Austenitic stainless steels, containing $19 \mathrm{w} / \mathrm{o}$ chromium and $9 \mathrm{w} / \mathrm{o}$ nickel, and suitably quench annealed, usually are found resistant to boiling $65 \mathrm{w} / \mathrm{o}$ reagent-grade nitric acid in laboratory corrosion tests. However, digest liquor from the refinery contains not only free nitric acid but also a variety of other ions in addition to large 
TABLE 2. STABILITY OF REFERENCE DIGEST LIQUORS IN CONTACT WITH TYPE 347 STAINLESS STEEL

\begin{tabular}{|c|c|c|c|c|c|c|c|}
\hline \multirow{3}{*}{$\begin{array}{c}\text { Exposure } \\
\text { Time, } \\
\text { hours }\end{array}$} & \multicolumn{7}{|c|}{ Analyzed Constituents, g per liter } \\
\hline & \multirow{2}{*}{$\begin{array}{c}\text { Free } \\
\text { Nitric } \\
\text { Acid }\end{array}$} & \multicolumn{2}{|l|}{ Total } & \multirow[b]{2}{*}{ Phosphate } & \multirow{3}{*}{ Fluoride } & \multirow{3}{*}{ Chloride } & \multirow{3}{*}{ Arsenate } \\
\hline & & $\begin{array}{c}\text { Total } \\
\text { Nitrate }\end{array}$ & Sulfate & & & & \\
\hline \multicolumn{5}{|c|}{ Reference 80 Liquor } & & & \\
\hline 0 & 385. & 459. & 17.4 & 0.80 & 0.09 & 0.042 & 0.004 \\
\hline 16 & 384. & 422. & 17.9 & 0.80 & $<0.02$ & 0.037 & 0.006 \\
\hline 42 & 385. & 450 & 17.9 & 0.80 & 0.03 & 0.036 & 0.007 \\
\hline 96 & 375. & 461. & 18.0 & 0.79 & -- & 0.030 & 0.008 \\
\hline 192 & 393. & 400 & 16.5 & 0.75 & 0.03 & 0.032 & 0.005 \\
\hline \multicolumn{8}{|c|}{ Reference 250 Liquor } \\
\hline 0 & 58.7 & 372. & 50.3 & 2.3 & 0.27 & 0.044 & 0.02 \\
\hline 16 & 54.8 & 350. & 55.2 & 2.9 & 0.38 & 0.025 & 0.03 \\
\hline 42 & 56.7 & 353. & 55.0 & 2.9 & 0.18 & 0.107 & 0.03 \\
\hline 96 & 54.3 & 349 & 50.3 & 2. 3 & - & 0.080 & 0.02 \\
\hline 192 & 53.4 & 292. & 53.2 & 2.7 & 0.19 & 0.040 & 0.02 \\
\hline
\end{tabular}


quantities of uranium nitrate. It was desired to know whether any of the se constituents would influence the behavior of stainless steel in nitric acid solutions.

The relative importance of each of the above solution variables to corrosion was evaluated in boiling digest-liquor solutions. The results are discussed under their appropriate headings in the sections which follow.

\section{Effect of Varying Nitric Acid and Uranium Contents}

Experiments were conducted in which the free nitric acid content of digest liquors was extended beyond the normal range found in practice. Digest liquors, with strengths ranging from 73.6 to $250 \mathrm{~g}$ uranium per liter, were studied at free nitric acid normality levels of $0.3,1,3,6$, and 9.1. The test results are summarized in Table 3, and plotted in Figures 1 and 2. Complete test data are to be found for various uranium concentrations and nitric acid levels in Table A-1 and for Reference 80 and Reference 250 liquors in Table A-2, respectively, in the Appendix.

\section{TABLE 3. EFFECT OF FREE NITRIC ACID AND URANIUM CONCENTRATION IN BOILING DIGEST LIQUOR ON THE RATE OF CORROSION OF UNWELDED TYPE 347 STAINLESS STEEL EXPOSED IN THE LIQUID PHASE}

\begin{tabular}{|c|c|c|c|c|c|c|}
\hline \multirow{2}{*}{$\begin{array}{c}\text { Free Nitric } \\
\text { Acid } \\
\text { Normality }\end{array}$} & \multicolumn{6}{|c|}{$\begin{array}{c}\text { Corrosion Rate, mils per month, at Indicated } \\
\text { Uranium Concentration, g per liter }\end{array}$} \\
\hline & 73.6 & 80 & 106. & 138. & 157. & 250. \\
\hline 0.3 & - & -- & -- & -- & 0.13 & -- \\
\hline 1. & -- & 0.29 & -- & -- & -- & 0.55 \\
\hline 3. & -- & -- & -- & 1.42 & 1.70 & 1. 84 \\
\hline 6. & -- & 1.52 & 2.57 & -- & 3.73 & -- \\
\hline 9.1 & 4.49 & -- & -- & -- & 9.12 & -- \\
\hline
\end{tabular}

If a corrosion rate of 2 mils per month, or lower, is considered satisfactory for the service life of the digesters, then reference to Figure l shows that a digest liquor containing $80 \mathrm{~g}$ uranium per liter does not become excessively corrosive until the free nitric acid concentration reaches approximately $7 N$. Similar threshold values are $4 N$ for liquors containing $157 \mathrm{~g}$ uranium per liter and $3 \mathrm{~N}$ for liquors containing $250 \mathrm{~g}$ uranium per liter.

Figure 2 depicts the effects of increasing the uranium concentration in liquors of constant nitric acid concentrations. As long as the free nitric acid of digest liquors was kept below $3 \mathrm{~N}$, the corrosion of Type 347 stainless steel specimens was not excessive 


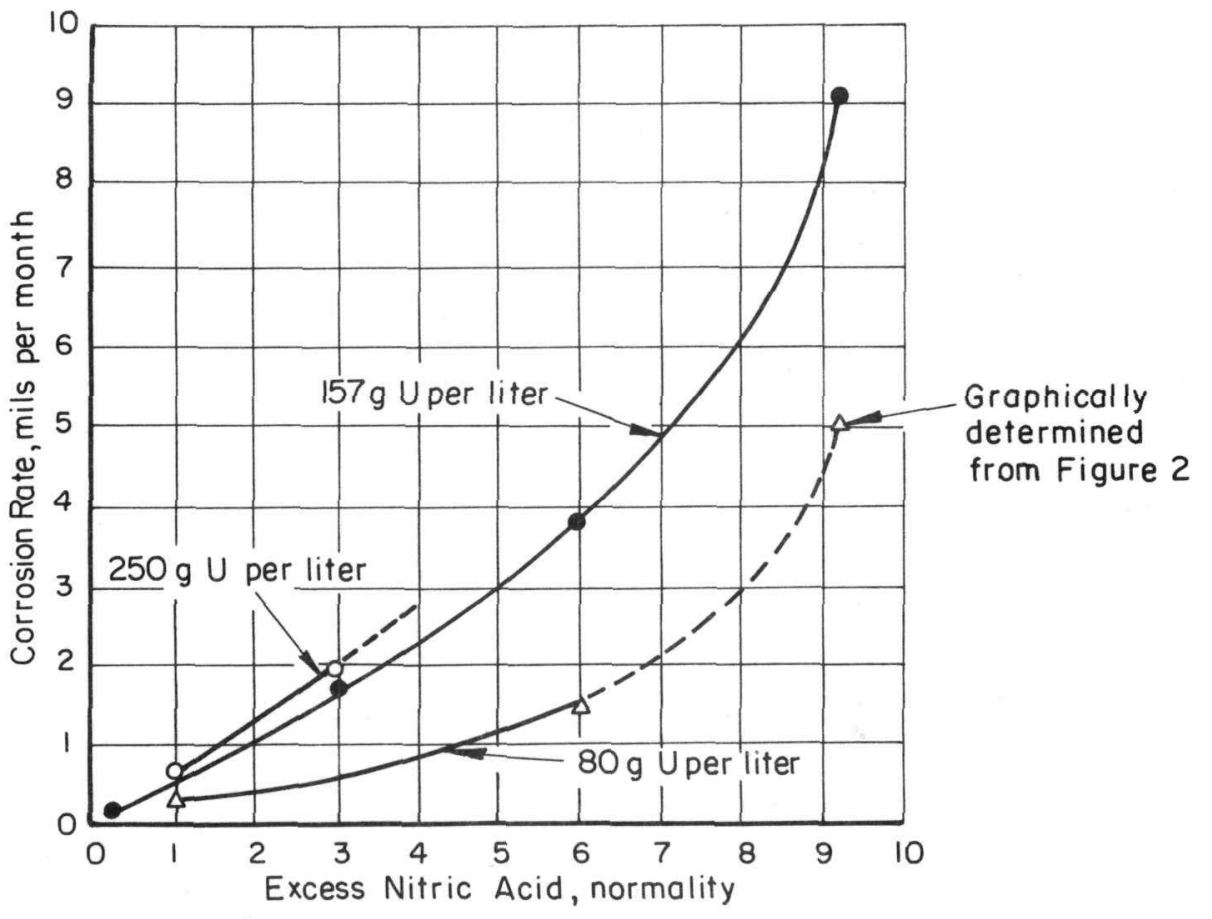

FIGURE 1. EFFECT OF EXCESS NITRIC ACID CONCENTRATION IN BOILING DIGEST LIQUOR ON THE CORROSION RATE OF TYPE 347 STAINLESS STEEL

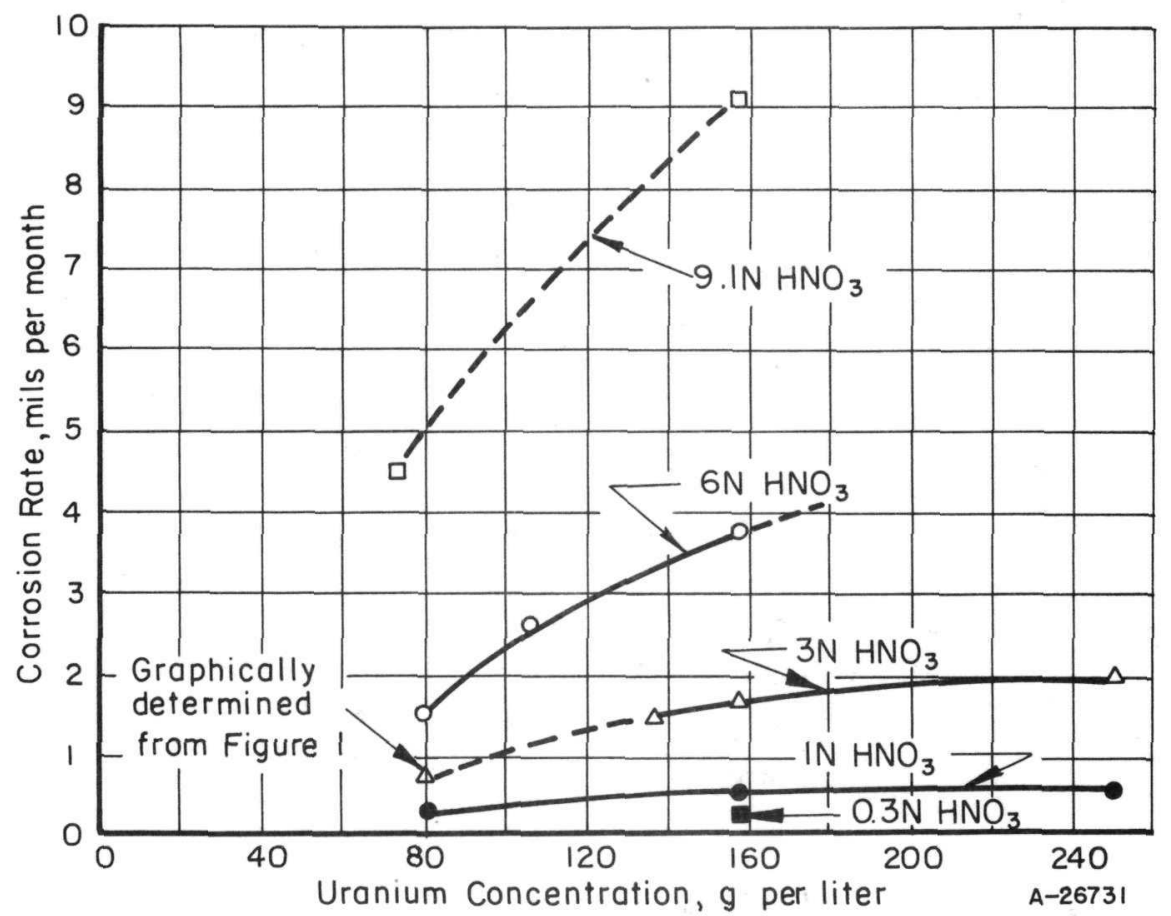

FIGURE 2. EFFECT OF URANIUM CONCENTRATION IN BOILING DIGEST LIQUOR ON THE CORROSION RATE OF TYPE 347 STAINLESS STEEL 
regardless of the uranium content of these liquors. When the free acid concentration was $6 \mathrm{~N}$, or higher, increasing the uranium content of the digest liquors resulted in more rapid corrosion of the Type 347 stainless steel.

\section{Effect of Minor Constituents From the Feed}

The range of concentrations of the various contaminating ions which were investigated in both Reference 80 and Reference 250 digest liquors are listed in Table 4 . Summaries of the corrosion data obtained with the se particular contaminants are shown in Tables 5 and 6. Data shown in these tables are for liquid-phase specimens. Complete results, which include data obtained for specimens exposed in the vapor phase and at the solution-vapor interface as well as in the liquid phase, are given in Tables A- 3 to A-10 in the Appendix. The effect of each of the se additions of extraneous ions to boiling digest liquors is discussed in the following sections.

\section{TABLE 4. RANGE OF INDIVIDUAL ADDITIONS STUDIED IN REFERENCE DIGEST LIQUORS}

\begin{tabular}{llcc}
\hline & \multicolumn{1}{c}{ Form } & \multicolumn{2}{c}{ Concentration Range, g per liter } \\
\cline { 3 - 4 } Ion Addition & & Reference 80 Liquor & Reference 250 Liquor \\
Fluoride & Hydrofluoric acid & $0.097-9.7$ & $0.30-30.2$ \\
Chloride & Hydrochloric acid & $0.056-13.4$ & $0.18-42.0$ \\
& & & $57.3-230$ \\
Sulfate & Sulfuric acid & $18.3-100$ & $2.29-11.5$ \\
Phosphate & Phosphoric acid & $0.73-3.65$ & $0.027-2.5$ \\
Arsenate & Arsenic acid & $0.009-0.80$ & -- \\
Abrasive & Silica sand (minus 100 & 240 & \\
& mesh & & \\
\hline \hline
\end{tabular}

\section{Fluoride Ion}

By the laboratory study, the fluoride ion was found to increase the corrosivity of digest liquors to Type 347 stainless steel to a greater extent than any of the other ions which are normally present in these plant solutions. Tests were made in which fluorides were added to both the Reference 80 and Reference 250 liquors. About $19 \mathrm{~g}$ per liter of fluorides can be tolerated in the Reference 250 liquor, but the presence of more than $0.75 \mathrm{~g}$ per liter fluorides in the Reference 80 liquor resulted in corrosion rates exceeding 2 mils per month. Data from the se tests, tabulated in Tables 5 and 6 , are shown graphically in Figure 3. Complete test data are in Tables A-3 and A-4 in the Appendix.

The corrosivity of the Reference 80 liquor, with its high (6N) free nitric acid content, is much more sensitive than the Reference 250 liquor to fluoride contamination. It seems reasonable to believe that the concentration of some of the metal ions present in the Reference 250 liquor, for example, aluminum, of which there is approximately 
TABLE 5. EFFECT OF ANION ADDITIONS TO BOILING REFERENCE 80 LIQUOR ON THE CORROSION OF TYPE 347 STAINLESS STEEL IMMERSED IN THE LIQUID PHASE

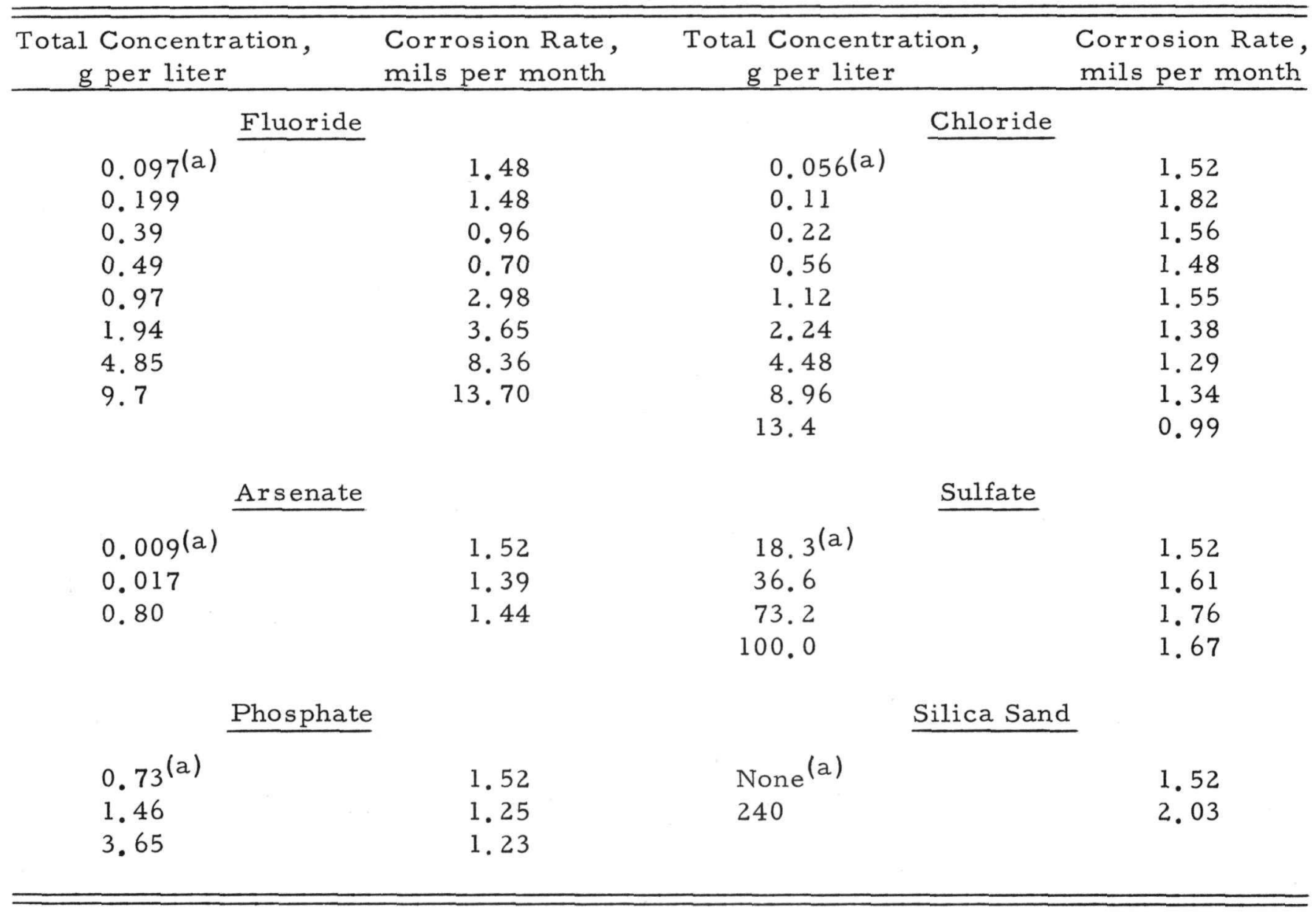

(a) Initial concentration in Reference 80 liquor. 
TABLE 6. EFFECT OF ANION ADDITIONS TO BOILING REFERENCE 250 LIQUOR ON THE CORROSION OF TYPE 347 STAINLESS STEEL IMMERSED IN THE LIQUID PHASE

\begin{tabular}{|c|c|c|c|c|c|}
\hline \multicolumn{2}{|c|}{$\begin{array}{l}\text { Total Concentration, } \\
\text { g per liter }\end{array}$} & \multirow[t]{2}{*}{$\begin{array}{l}\text { Corrosion Rate, } \\
\text { mils per month }\end{array}$} & \multicolumn{2}{|c|}{$\begin{array}{l}\text { Total Concentration, } \\
\text { g per liter }\end{array}$} & $\begin{array}{l}\text { Corrosion Rate, } \\
\text { mils per month }\end{array}$ \\
\hline & Fluoride & & & Chloride & \\
\hline $0.30(a)$ & & 0.17 & $0.18(a)$ & & 0.55 \\
\hline 0.60 & & 0.59 & 0.35 & & 0.59 \\
\hline 1.21 & & 0.58 & 0.70 & & 0.55 \\
\hline 1.51 & & 0.38 & 1.75 & & 0.57 \\
\hline 3.02 & & 0.44 & 3.5 & & 0.83 \\
\hline 15.1 & & 1.28 & 7.0 & & 1.00 \\
\hline \multirow[t]{3}{*}{30.2} & & 5.20 & 14.0 & & 1. 14 \\
\hline & & & 28.0 & & 1.22 \\
\hline & Arsenate & & 42.0 & & 1.33 \\
\hline $0.027(a)$ & & 0.55 & & & \\
\hline 0.054 & & 0.62 & & Sulfate & \\
\hline \multirow[t]{3}{*}{2.5} & & 0.58 & $57.3(a)$ & & 0.55 \\
\hline & & & 115 & & 0.95 \\
\hline & Phosphate & & 230 & & 1.20 \\
\hline 2. $29(a)$ & & 0.55 & & & \\
\hline 4.58 & & 0.58 & & & \\
\hline 11.45 & & 0.59 & & & \\
\hline
\end{tabular}

(a) Initial concentration in Reference 250 liquor. 
$6 \mathrm{~g}$ per liter, is sufficient to form complexes with the fluorides and thus to inactivate a major fraction of the highly corrosive fluoride ions.

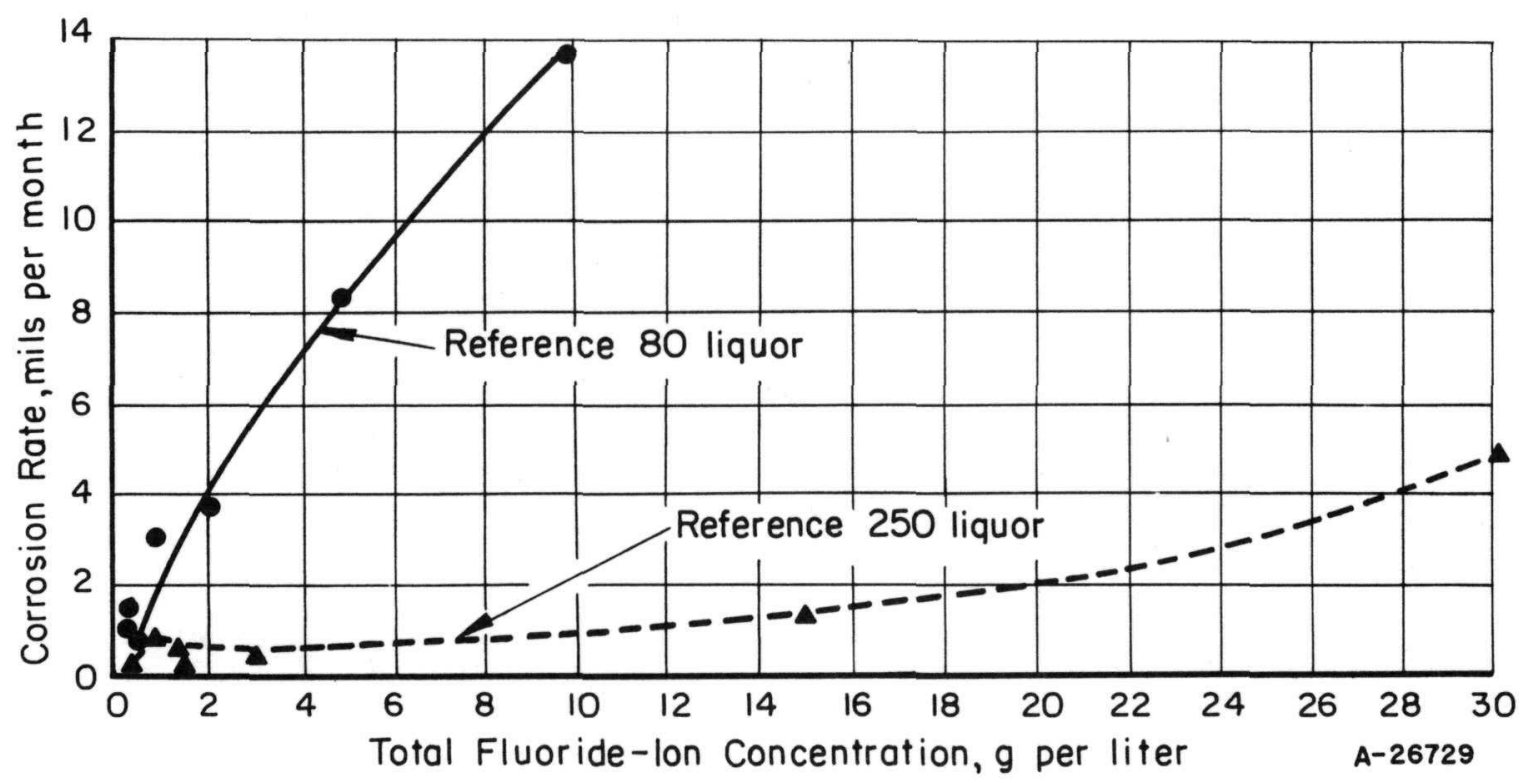

FIGURE 3. CORROSION BEHAVIOR OF UNWELDED TYPE 347

STAINLESS STEEL EXPOSED IN BOILING REF-

ERENCE 80 AND REFERENCE 250 LIQUORS WITH

FLUORIDE ADDITIONS

Both Reference 80 and Reference 250 liquors when fortified with a fluoride concentration far in excess of that normally expected in service selectively attack the welds of Type 347 stainless steel. Calculations have shown this weld-zone attack to be three to five times more severe than the attack occurring on the unwelded portions of the specimens.

\section{Chloride Ion}

No significant increase in the rate of attack of plant digest liquors on Type 347 stainless steel specimens in the liquid or vapor phase could be attributed to the presence of the chloride ion. This was substantiated by tests in which up to $13.4 \mathrm{~g}$ per liter of chloride ion, as hydrochloric acid, was added to Reference 80 liquors and up to $42 \mathrm{~g}$ per liter to Reference 250 liquors. These additions are far in excess of normal chloride concentrations in either liquor. Neither was there any indication of intergranular or pitting attack on welded or unwelded specimens.

Summary results of the se tests are included in Tables 5 and 6 , and complete data are in Tables A-5 and A-6 in the Appendix.

Arsenate, Phosphate, and Sulfate Ions

Additions of arsenate, phosphate, and sulfate were studied individually in Reference 80 and Reference 250 liquors to observe their effects on the corrosivity of the se 
liquors. For these experiments the solutions were adjusted to contain up to one hundred times the amount of arsenate, five times the amount of phosphate, and four to five times the amount of sulfate normally present in these two plant liquors. These additions did not result in a significant increase in the corrosivity of the se liquors on Type 347 stainless steel specimens. Summarized results are tabulated in Tables 5 and 6, and complete data are in Tables A-7, A-8, and A-9, in the Appendix.

\section{Abrasives}

To assess the amount of erosion-corrosion which might result from abrasive materials present in the concentrate, $240 \mathrm{~g}$ per liter of minus 100 -mesh silica sand was added to Reference 80 and Reference 250 liquors. Specimens of Type 347 stainless steel showed no significantly increased corrosion from exposure to the se boiling slurries even when extraneous ions such as phosphate or sulfate were added. Summary results of the se experiments are given in Table 5 and complete data are in Table A-10 in the Appendix.

\section{Effect of Aluminum on Corrosion by Fluoride}

Aluminum was added to two Reference 80 digest liquors which contained 4.85 and $9.7 \mathrm{~g}$ per liter fluoride, respectively, and to Reference 250 liquor which contained 30.2 g per liter fluoride.

Since the reference digest liquors already contained a substantial amount of aluminum, liquors of similar compositions, but containing only uranium, free nitric acid, and fluoride, were prepared for comparative tests of the effects of aluminum additions. Such solutions are hereinafter referred to as simulated digest liquors.

The relative attack of the reference and simulated liquors with added fluoride on Type 347 stainless steel is reported in Table 7. It may be seen that the Simulated 80 and 250 digest liquors are significantly more corrosive than the corresponding reference liquors. This difference may be entirely attributable to the aluminum already present in the reference liquors, or to certain other metallic ions, which, in addition to aluminum, have been shown to be partially effective in complexing fluoride. (See for example the research conducted with iron, cobalt, and nickel in BMI-927. (1))

\section{Plant and Simulated Digest Liquor}

To demonstrate the effect of aluminum on the corrosion rate, additions up to $25 \mathrm{~g}$ per liter were made to Reference and Simulated 80 digest liquors, and additions up to $37.5 \mathrm{~g}$ per liter were made to both of the 250 liquors. Results for Type 347 stainless steel specimens exposed in the se solutions, to which fluoride also had been added, are presented in Table 8. The data for Reference and Simulated 80 liquors are plotted in Figure 4, and a similar plot for Reference and Simulated 250 liquors appears in Figure 5.

(1) References at end. 
TABLE 7. THE EFFECT OF FLUORIDE ADDITIONS TO REFERENCE AND SIMULATED DIGEST LIQUORS ON THE CORROSION OF TYPE 347 STAINLESS STEELS

\begin{tabular}{|c|c|c|c|}
\hline $\begin{array}{c}\text { Total Fluoride } \\
\text { Present, g per liter }\end{array}$ & $\begin{array}{l}\text { Corrosion Rate, } \\
\text { mils per month }\end{array}$ & $\begin{array}{c}\text { Total Fluoride } \\
\text { Present, g per liter }\end{array}$ & $\begin{array}{l}\text { Corrosion Rate, } \\
\text { mils per month }\end{array}$ \\
\hline \multicolumn{2}{|c|}{ Reference 80 Liquor } & \multicolumn{2}{|c|}{ Simulated 80 Liquor } \\
\hline $0 . \overline{39}$ & 0.96 & $0 . \overline{39}$ & 1,33 \\
\hline 1.94 & 3.65 & 1.94 & 15.3 \\
\hline 4.85 & 8.36 & 4.85 & 23.6 \\
\hline 9.7 & 13.70 & 9.7 & -- \\
\hline \multicolumn{2}{|c|}{ Reference 250 Liquor } & \multicolumn{2}{|c|}{ Simulated 250 Liquor } \\
\hline $3 . \overline{02}$ & 0.44 & $3 . \overline{02}$ & 1.25 \\
\hline 7.55 & -- & 7.55 & 3.54 \\
\hline 15.1 & 1.28 & 15.1 & 21.6 \\
\hline 30.2 & 5. 20 & 30.2 & 23.6 \\
\hline
\end{tabular}


TABLE 8. DATA COMPARING THE EFFECTS OF ALUMINUM ADDITIONS TO REFERENCE AND SIMULATED LIQUORS WITH ADDED FLUORIDE ON THE CORROSION OF TYPE 347 STAINLESS STEEL

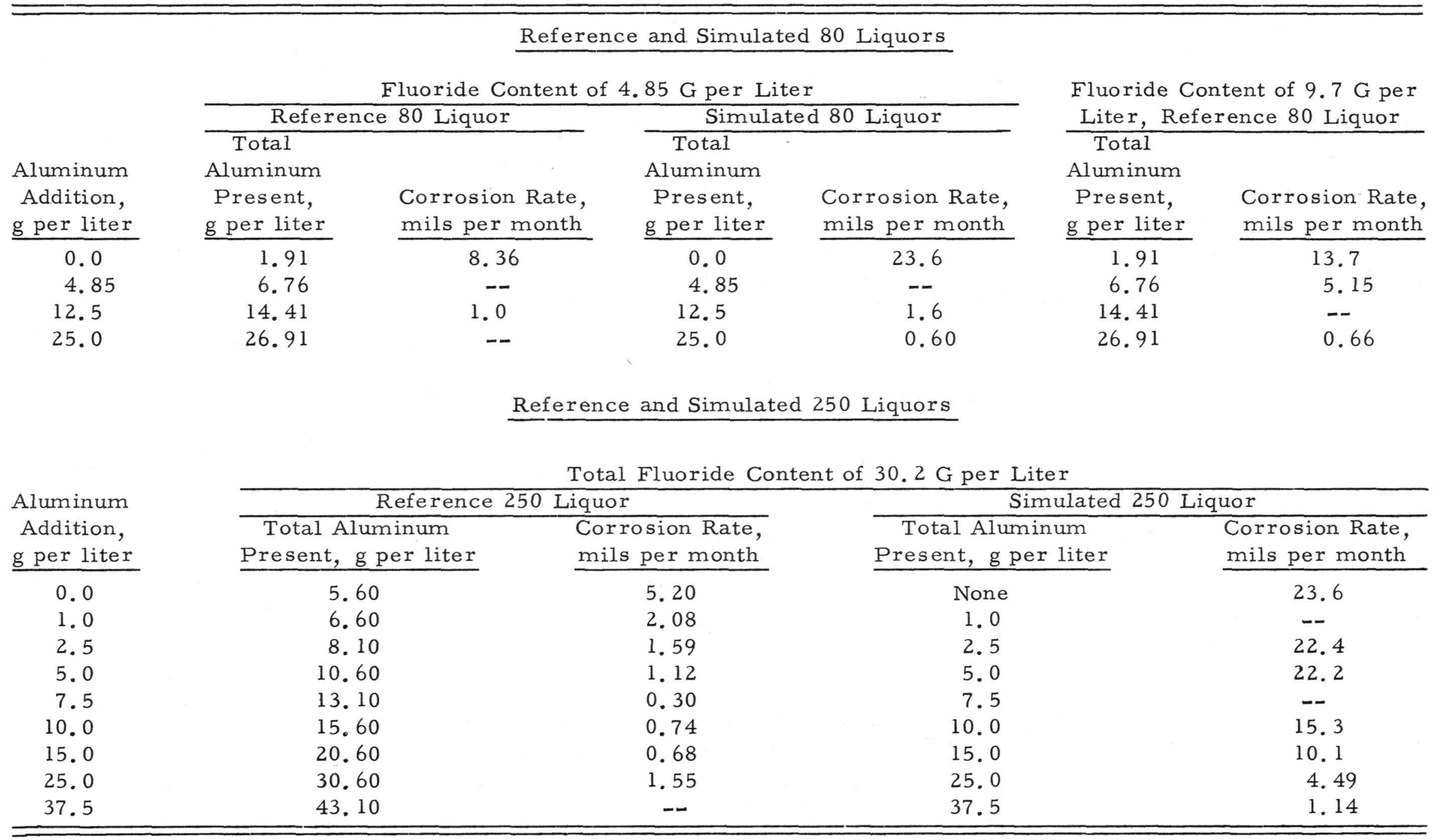




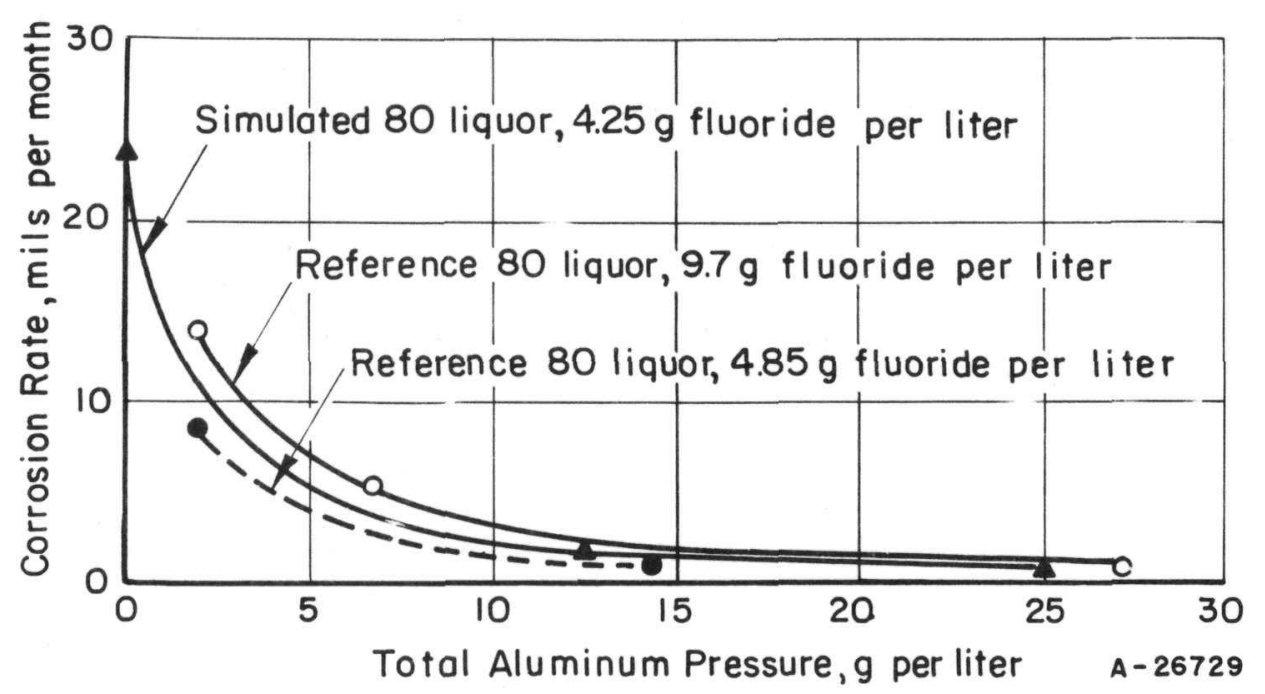

FIGURE 4. THE EFFECT OF ALUMINUM ADDITIONS TO FLUORIDECONTAMINATED REFERENCE 80 AND SIMULATED 80 DIGEST LIQUORS ON THE CORROSION RATE OF TYPE 347 STAINLESS STEEL

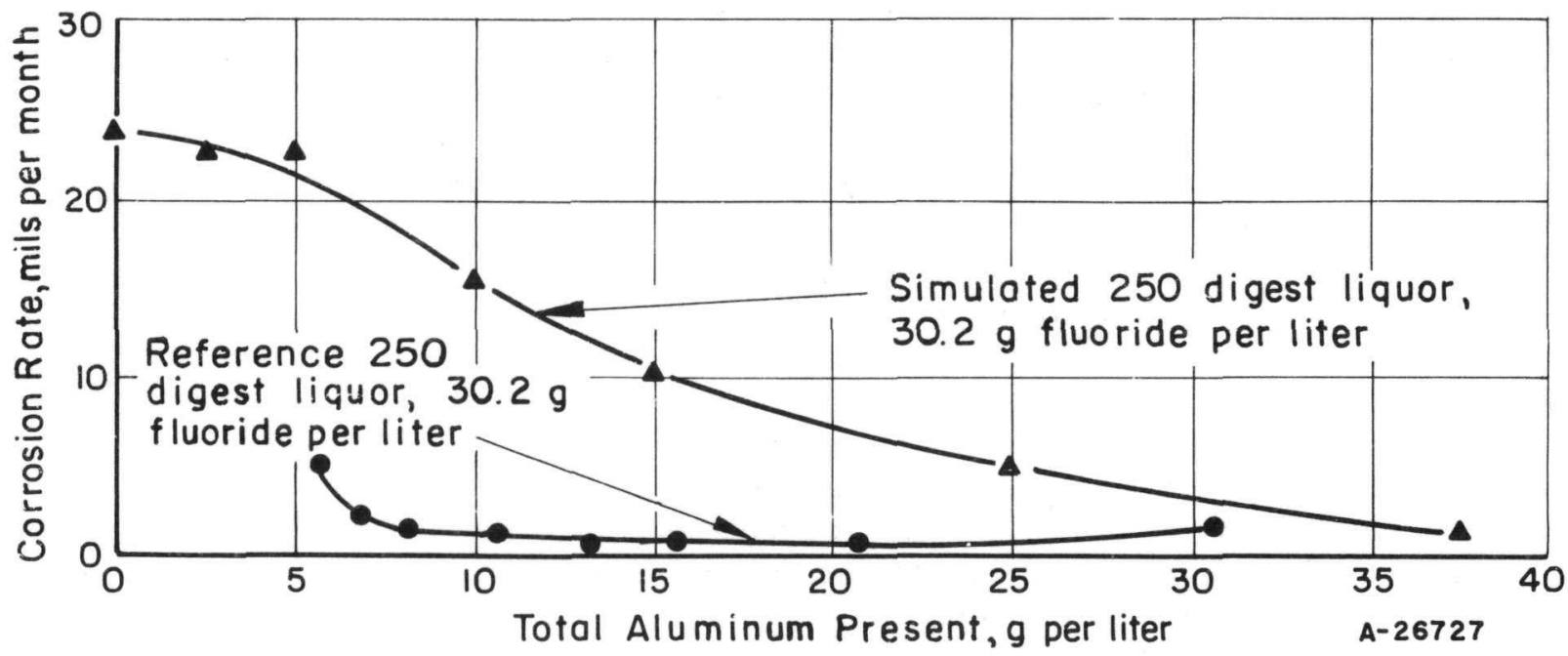

FIGURE 5. THE EFFECT OF ALUMINUM ADDITIONS TO FLUORIDECONTAMINATED REFERENCE 250 AND SIMULATED 250 AND SIMULATED 250 DIGEST LIQUORS ON THE CORROSION RATE OF TYPE 347 STAINLESS STEEL 
The corrosion-inhibiting effects of aluminum appear to be comparable in the Reference 80 and Simulated 80 liquors, as shown in Figure 4. The corrosiveness of the se liquors to Type 347 stainless steel was reduced to approximately 2 mils per month by the presence of about 2 to $3 \mathrm{~g}$ of aluminum per $\mathrm{g}$ of fluoride.

A comparison of the Reference 250 and Simulated 250 liquors, as shown in Figure 5, indicates that the simulated liquor requires much more aluminum than the reference liquor in order to reduce the corrosion to a tolerable level.

While some of the se test liquors contained far greater concentrations of fluoride than would be expected in normal digest liquors, it is conceivable that new sources of concentrates might produce liquors which are high in fluorides and low in aluminum. In the event that such unfortunate combinations occur, proper balancing of the fluoride concentration with aluminum additions could be used to inhibit the corrosion of Type 347 stainless steel by such liquors.

The fluoride present in early-stage digest liquors requires a much higher aluminum concentration to suppress its corrosivity. A ratio of about 3 parts aluminum to 1 part fluoride, by weight, based on the fluoride concentration at the start of digestion, should be adequate to keep corrosion below the figure of 2 mils per month.

Vapor Phase

A comparison of the corrosion rates of Type 347 stainless steel specimens in both the liquid and vapor-phase positions of exposure in Reference 80 and Reference 250 digest liquors containing 9.7 and 30.2 g per liter fluoride, respectively, is shown in Table 9. The se data clearly show the simultaneous reduction in corrosivity which occurs in both the liquid and vapor phases upon addition of aluminum. This constitutes further evidence that aluminum not only sequesters the fluoride ion but also decreases its volatility. It is reported that actual experience at the Mallinckrodt refinery with the digest liquors has shown that fluoride ion carry-over to other equipment via the vapor route has been greatly diminished by the presence of aluminum in the solution.

\section{Effect of Iron on Corrosion by Chloride}

Chloride ions are recognized as being corrosive toward stainless steels, and the corrosion is usually in the form of pitting. As already stated, an addition of a considerable excess of chloride above that already present in plant digest liquor did not result in increased corrosion of Type 347 stainless steel. However, in the event that the composition of the feed material might change substantially in the future, study was made of the effect of chloride on the corrosion of this material.

\section{Simulated Digest Liquors}

Chloride was added to a series of simulated digest liquors containing varying concentrations of nitric acid and uranium, but without the other usual extraneous ions, in order that the safe operating ranges in the presence of chloride might be better defined. 
TABLE 9. THE EFFECT OF ALUMINUM ADDITIONS TO BOILING FLUORIDECONTAMINATED REFERENCE 80 AND 250 DIGEST LIQUORS ON THE RATE OF ATTACK ON TYPE 347 STAINLESS STEEL

\begin{tabular}{|c|c|c|c|}
\hline \multicolumn{2}{|c|}{$\begin{array}{c}\text { Reference } 80 \text { Liquor With } 9.7 \text { G per } \\
\text { Liter Fluoride }\end{array}$} & \multicolumn{2}{|c|}{$\begin{array}{l}\text { Reference } 250 \text { Liquor With } 30.2 \mathrm{G} \text { per } \\
\text { Liter Fluoride }\end{array}$} \\
\hline $\begin{array}{l}\text { Aluminum Addition, } \\
\text { g per liter }\end{array}$ & $\begin{array}{l}\text { Corrosion Rate, } \\
\text { mils per month }\end{array}$ & $\begin{array}{l}\text { Aluminum Addition, } \\
\text { g per liter }\end{array}$ & $\begin{array}{l}\text { Corrosion Rate, } \\
\text { mils per month }\end{array}$ \\
\hline \multicolumn{4}{|c|}{ Vapor-Phase Samples } \\
\hline 0 & 16. & 0 & 4.8 \\
\hline 5 & 4.9 & 5 & 2.1 \\
\hline 25 & 0.84 & 10 & 1.2 \\
\hline \multicolumn{4}{|c|}{ Liquid-Phase Samples } \\
\hline 0 & 59. & 0 & 4.7 \\
\hline 5 & 5.2 & 5 & 1.3 \\
\hline 25 & 0.69 & 10 & 0.74 \\
\hline
\end{tabular}


These test liquors were of the following compositions:

$\begin{array}{cccc}\text { Liquor } & \text { Nitric Acid } & & \text { Uranium, g per liter } \\ 1 & 3 \mathrm{~N} & \text { None } & 42 \\ 2 & 6 \mathrm{~N} & \text { None } & 42 \\ 3 & 6 \mathrm{~N} & 80 & 42 \\ 4 & 3 \mathrm{~N} & 250 & 42\end{array}$

The simulated digest liquors with added chloride were found to be very corrosive to Type 347 stainless steel. Both pitting and severe surface attack were observed. The presence of uranium in the se solutions had little effect on the degree of corrosivity. However, additions of iron, in the form of ferric ions, were successfully used to combat the corrosion promoted by the chloride. Results of such experiments, listed in Table 10, indicate that 20 and $40 \mathrm{~g}$ per liter ferric iron would inhibit the attack on Type 347 stainless steel in simulated digest liquors containing $42 \mathrm{~g}$ per liter chloride.

TABLE 10. THE EFFECT OF IRON ADDITIONS TO FOUR SIMULATED LIQUORS CONTAINING 42 G PER LITER CHLORIDE ON THE CORROSION OF TYPE 347 STAINLESS STEEL

\begin{tabular}{ccccc}
\hline \hline $\begin{array}{c}\text { Iron Addition, } \\
\text { g per liter }\end{array}$ & \multicolumn{4}{c}{ Corrosion Rate, mils per month } \\
\cline { 2 - 5 } 0 & 3.2 & Liquor $(\mathrm{b})$ & Liquor $(\mathrm{c})$ & Liquor $(\mathrm{d})$ \\
\hline 20 & 1.1 & 5.3 & 6.5 & 0.6 \\
40 & 1.3 & 0.54 & 0.46 & 0.71 \\
& & -- & -- & 0.51 \\
\hline \hline
\end{tabular}

(a) Liquor $1,3 \mathrm{~N} \mathrm{HNO}_{3}, 42 \mathrm{~g}$ chloride per liter.

(b) Liquor 2, $6 \mathrm{~N} \mathrm{HNO}_{3}, 42 \mathrm{~g}$ chloride per liter.

(c) Liquor $3,6 \mathrm{~N} \mathrm{HNO}_{3}, 80 \mathrm{~g}$ uranium per liter, $42 \mathrm{~g}$ chloride per liter

(d) Liquor 4, 3N $\mathrm{HNO}_{3}, 250 \mathrm{~g}$ uranium per liter, $42 \mathrm{~g}$ chloride per liter.

The digest liquor supplied by the Mallinckrodt refinery for the se experiments contained about $20 \mathrm{~g}$ per liter of extraneous metal ions in addition to uranium. These metals were principally aluminum, cobalt, iron, and nickel. Apparently the same type of reduction of the corrosion by chloride ions is provided naturally by the metal ions in plant digest liquors as was afforded chloride-contaminated simulated digest liquors by the addition of ferric iron.

\section{Plant Liquors}

The addition of ferric iron to Reference 80 and 250 digest liquors containing $42 \mathrm{~g}$ per liter chloride did not result in corrosion inhibition. Rather, the corrosive attack was somewhat increased by the presence of up to $40 \mathrm{~g}$ per liter ferric ion. The increase in corrosion rates which occurred when the ferric iron additions were made are shown in Table 11 and in Figure 6. Even with this increased rate of attack no severe localized attack of the stainless steel specimens was observed in the reference 
solutions. It would appear that the metallic ions in the plant liquor, which are responsible for the corrosion inhibition, are present in approximately the optimum concentration, and thus further additions of iron are detrimental rather than helpful.

TABLE 11. THE EFFECT OF IRON ADDITIONS ON THE CORROSION OF TYPE 347 STAINLESS STEEL EXPOSED TO REFERENCE LIQUORS CONTAINING 42 G PER LITER CHLORIDE

\begin{tabular}{ccc}
\hline \hline $\begin{array}{c}\text { Iron Addition, } \\
\text { g per liter }\end{array}$ & \multicolumn{2}{c}{ Corrosion Rate, mils per month } \\
\cline { 2 - 3 } None & 0.92 & Reference 250 Liquor \\
10 & -- & 1.32 \\
20 & 2.08 & 1.90 \\
30 & -- & 2.01 \\
40 & 3.88 & 2.35 \\
\hline
\end{tabular}

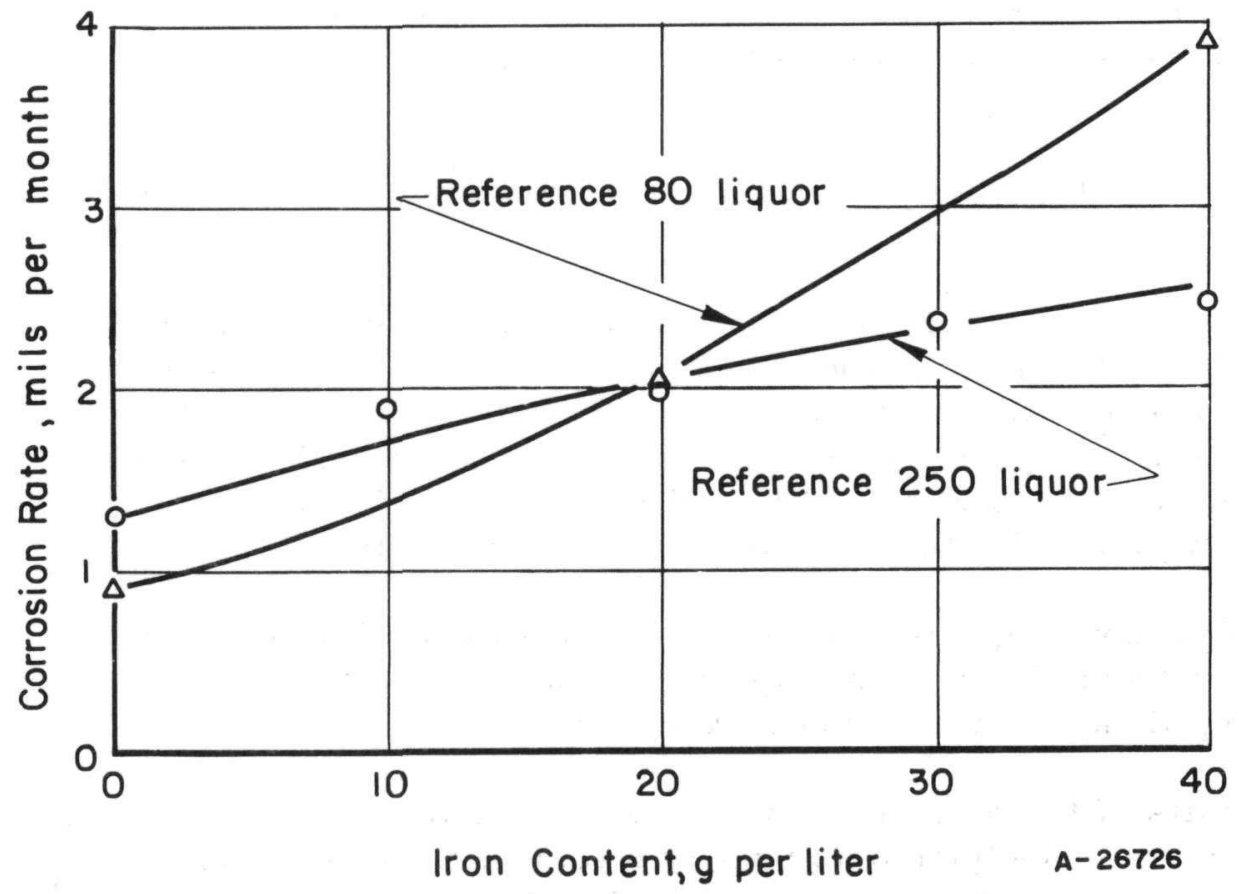

FIGURE 6. THE EFFECT OF IRON ADDITIONS ON THE CORROSION OF TYPE 347 STAINLESS STEEL BY REFERENCE LIQUORS CONTAINING 42 G PER LITER CHLORIDE 
Resistance of Other Stainless Alloys to Digest

Liquors Containing Fluoride Ion

It seemed possible that some of the other stainless alloys might exhibit better corrosion resistance to high-fluoride-content digest liquors than had been obtained with Type 347 stainless steel. Consequently, a selection of stainless alloys, along with Type 347 stainless steel for comparison, were evaluated for corrosion behavior in both the Reference 250 liquor and in Simulated 250 liquor containing only uranium and nitric acid. An addition of $30.2 \mathrm{~g}$ per liter of fluoride was made to both liquors. Corrosion at welds and heat-affected areas was particularly noted. Welded specimens of Types 347 and 304 ELC stainless steel, Carpenter No. 20 stainless with and without added niobium, and Haynes Alloy No. 25 were tested.

All welds were made using proprietary electrodes recommended for the alloy. All of the alloys were tested in the as-welded condition, and all but the Haynes Alloy No. 25 specimens were tested after quench annealing. The results of the se exposures, along with the annealing details, are presented in Table 12. Photographs of the specimens after exposure are shown in Figures 7 and 8 . The attack at the welds and heataffected areas adjacent to the welds may be seen.

None of the alloys evaluated are significantly better than Type 347 stainless steel, but Type 304 ELC appears to be quite comparable. Both of the Carpenter alloys suffered significant attack in the heat-affected areas. This attack was not materially reduced by quench annealing. Haynes Alloy No. 25 corroded at a comparatively low rate. However, a loose insoluble corrosion deposit formed on the surface of the specimens. A considerable amount of surface spalling occurred during testing. Such a condition might be considered undesirable for service in digesters.

\section{Digest Liquors From More Recent Production}

All of the investigations conducted on plant digest liquors were based on the supply received from the Mallinckrodt Uranium Refining Center in August, 1951. In order that the corrosiveness of the digest liquors in more recent production might be compared under similar experimental conditions, four additional digest liquors were supplied by Mallinckrodt in January, 1955. The analyses and descriptions of the se four liquors are compared with the original test liquor in Table 13.

Each of the four liquors was used to make reference liquors similar to the original Reference 80 and 250 liquors. Specimens of Type 347 stainless steel were exposed in the se boiling liquors for four $96-\mathrm{hr}$ test periods.

The results of the tests are summarized in Table 14. Two of the new samples of plant digest liquors, designated as "regular soluble feed" and "salted black oxide feed", were found to be several times more corrosive than the original digest liquor. As analyzed, the se two liquors contain three to five times the fluoride content of the original digest liquor. The fluoride content probably contributed to the observed increase in corrosivity. These more corrosive liquors did not produce severe localized attack such as pitting, or attack at the welds of the Type 347 stainless steel to a greater extent than the older liquor. 
TABLE 12. THE CORROSION OF STAINLESS ALLOYS EXPOSED TO BOILING REFERENCE 250 AND SIMULATED 250 DIGEST LIQUORS CON'TAINING 30.2 G PER LITER ADDED FLUORIDE

Samples in the Liquid Phase for Four 90-Hr Test Periods

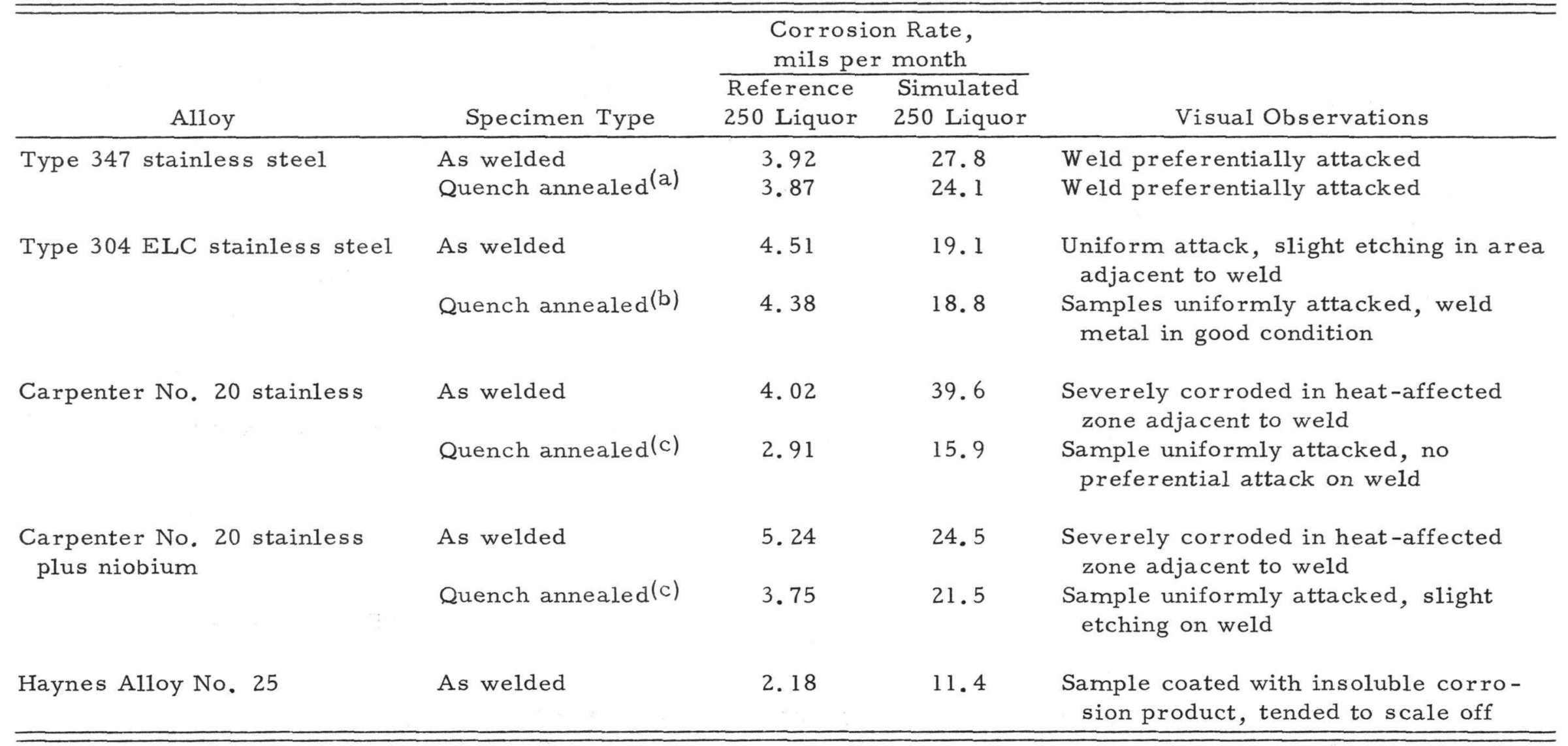

\footnotetext{
(a) Air-atmosphere anneal for $1 \mathrm{hr}$ at $2000 \mathrm{~F}$, water quench.

(b) Air-atmosphere anneal for $1 \mathrm{hr}$ at $1800 \mathrm{~F}$, water quench.

(c) Air-atmosphere anneal for $1 \mathrm{hr}$ at $2050 \mathrm{~F}$, water quench.
} 
Reference 250 Liquor, $\frac{30.2 \mathrm{G} \text { per Liter Fluoride }}{\text { Quench }}$

As Welded

$$
\text { Annealed }
$$

Type 347 Stainless Steel

Corrosion Rate, mils per month

Type 304 ELC

Stainless Steel

Corrosion Rate, mils per month

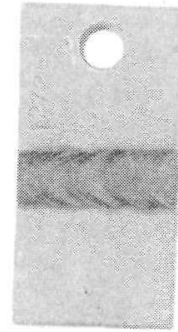

3.92

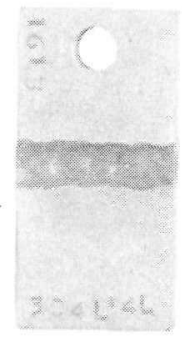

4.51
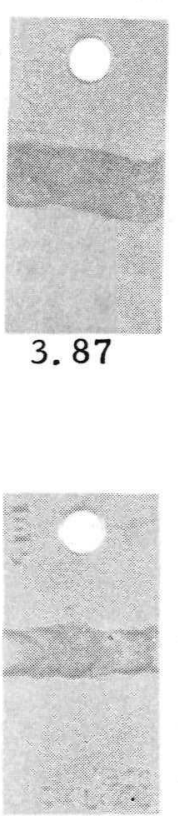

4. 38
Simulated 250 Liquor, 30.2 G per Liter Fluoride Quench

As Welded

Annealed
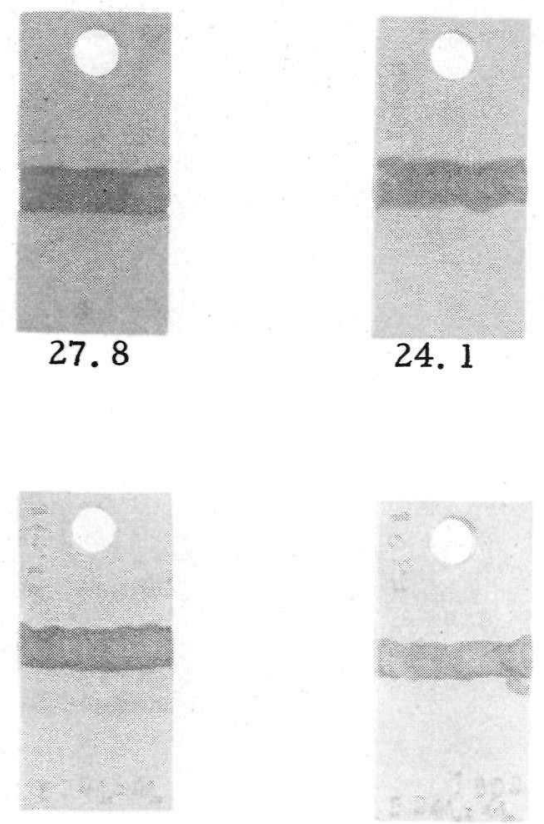

19. 1

18.8

FIGURE 7. STAINLESS ALLOYS AFTER EXPOSURE TO BOILING REFERENCE AND SIMULATED DIGEST LIQUORS FOR FOUR 96-HR TEST PERIODS 
Reference 250 Liquor, 30.2 G per Liter Fluoride

As Welded Annealed

Carpenter No. 20 Stainless

Corrosion Rate, mils per month

Carpenter No. 20 Stainless, With Niobium

Haynes Alloy No. 25

Corrosion Rate, mils per month

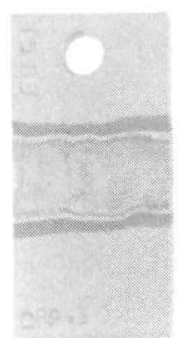

4. 02

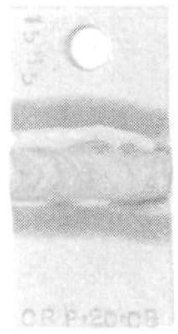

5. 24

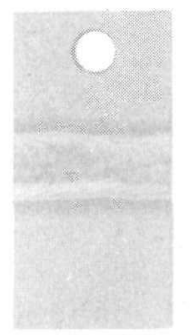

2. 18
Simulated 250 Liquor, 30. $2 \mathrm{G}$ per Liter Fluoride Quench

As Welded

Annealed

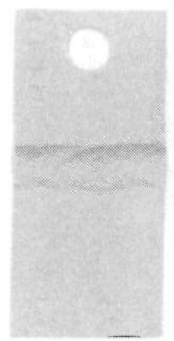

39.6

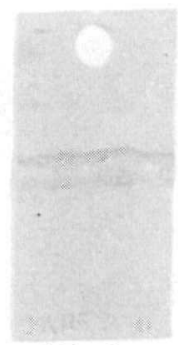

15. 9
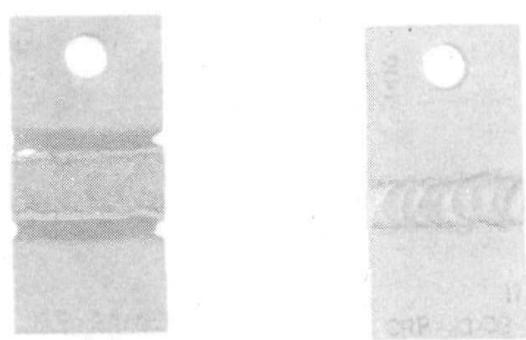

24.5

21.5

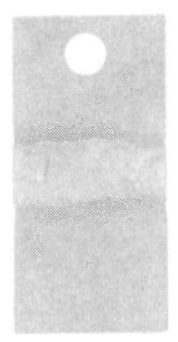

11. 4

FIGURE 8. STAINLESS ALLOYS AFTER EXPOSURE TO BOILING REFERENCE AND SIMULATED DIGEST LIQUORS FOR FOUR 96-HR TEST PERIODS 
TABLE 13. ANALYSIS OF DIGEST LIQUORS RECEIVED FROM MALLINCKRODT URANIUM REFINING CENTER

\begin{tabular}{|c|c|c|c|c|c|c|c|c|c|c|c|}
\hline \multirow[b]{2}{*}{ Digest Liquor } & \multirow[b]{2}{*}{$\begin{array}{c}\text { Date } \\
\text { Received }\end{array}$} & \multicolumn{10}{|c|}{ Concentration, g per liter } \\
\hline & & Uranium & $\begin{array}{c}\text { Free } \\
\text { Nitric Acid }\end{array}$ & $\begin{array}{l}\text { Total } \\
\text { Nitrate }\end{array}$ & Sulfate & Phosphate & Fluoride & Chloride & Iron & Molybdenum & Vanadium \\
\hline \multicolumn{12}{|c|}{ As-Received Liquor } \\
\hline Sump recovery feed & January, 1955 & 207 & 27.4 & 362 & 0.31 & 1.2 & 0.88 & 0.16 & 2.5 & 0.06 & 0.20 \\
\hline Salted black oxide feed & January, 1955 & 181 & 24.9 & 365 & 11.7 & 8.8 & 1.17 & 0.16 & 8.0 & 0.02 & 1.5 \\
\hline Regular pitchblende feed & January, 1955 & 199 & 20.0 & 177 & 30.0 & 1.1 & 0.18 & 0.03 & 2.5 & 0.6 & 0.15 \\
\hline Regular soluble feed & January, 1955 & 180 & 21.0 & 338 & 1.5 & 3.0 & 0.42 & 0.17 & 2.5 & 0.02 & 0.8 \\
\hline Regular pitchblende feed & August, 1951 & 157 & 22.8 & 210 & 36.0 & 1. 44 & 0.19 & 0.11 & 2. 77 & 0.73 & 0.40 \\
\hline \multicolumn{12}{|c|}{ Analysis Calculated to Basis of $250 \mathrm{G}$ per Liter Uranium } \\
\hline Sump recovery feed & January, 1955 & 250 & 32.9 & 434 & 0.37 & 1.4 & 1.06 & 0.19 & 3.0 & 0.07 & 0.24 \\
\hline Salted black oxide feed & January, 1955 & 250 & 34.4 & 504 & 16.2 & 12.3 & 1.62 & 0.22 & 11.0 & 0.03 & 2.1 \\
\hline Regular pitchblende feed & January, 1955 & 250 & 25.1 & 222 & 37.7 & 1.4 & 0.23 & 0.04 & 3.1 & 0.8 & 0.19 \\
\hline Regular soluble feed & January, 1955 & 250 & 29.2 & 469 & 2.1 & 4. 16 & 0.58 & 0.24 & 3.5 & 0.03 & 1.1 \\
\hline Regular pitchblende feed & August, 1951 & 250 & 63.0 & 378 & 57.3 & 2.3 & 0.30 & 0.175 & 4. 40 & 1.16 & 0.64 \\
\hline
\end{tabular}


25 and 26

TABLE 14. DATA COMPARING THE CORROSION ON TYPE 347 STAINLESS STEEL EXPOSED TO THE ORIGINAL AND THE MORE RECENT DIGEST LIQUORS

\begin{tabular}{|c|c|c|c|c|c|c|c|}
\hline \multirow[b]{3}{*}{ Digest Liquor } & \multirow{3}{*}{$\begin{array}{c}\text { Date } \\
\text { Received }\end{array}$} & \multicolumn{6}{|c|}{ Corrosion Rate, mils per month } \\
\hline & & \multicolumn{3}{|c|}{ Reference 80 Liquor } & \multicolumn{3}{|c|}{ Reference 250 Liquor } \\
\hline & & Vapor & Interface & Liquid & Vapor & Interface & Liquid \\
\hline Sump recovery feed & January, 1955 & 1.65 & 1.59 & 1.65 & 0.27 & 1. 03 & 1.24 \\
\hline Salted black oxide feed & January, 1955 & 0.55 & 3.33 & 3.72 & 0.51 & 3.80 & 4.10 \\
\hline Regular pitchblende feed & January, 1955 & 0.53 & 0.78 & 0.96 & 0.11 & 0.56 & 0.73 \\
\hline Regular soluble feed & January, 1955 & 0.64 & 1.27 & 1.55 & 0.17 & 1.82 & 2.06 \\
\hline Regular pitchblende feed & August, 1951 & 0.83 & 2.66 & 2.42 & 0.25 & 0.70 & 1.37 \\
\hline
\end{tabular}

\section{REFERENCES}

(1) Peoples, R. S., Fink, F. W., Stewart, O. M., and Braun, W. J., "Corrosion of Type 347 Stainless Steel in Uranium Derby Pickle Bath", BMI-927 (July 14, 1954).

FWF:W JB:OMS/all 


\section{APPENDIX}

ADDITIONAL CORROSION DATA 
TABLE A-1. THE EFFECTS OF FREE NITRIC ACID AND URANIUM CONCENTRATIONS ON THE CORROSION OF TYPE 347 STAINLESS STEEL BY BOILING DIGEST LIQUORS

Samples Exposed in the Liquid Phase

\begin{tabular}{|c|c|c|c|c|c|c|c|c|c|c|c|c|c|}
\hline \multirow[b]{2}{*}{$\begin{array}{l}\text { Specimen } \\
\text { Type }\end{array}$} & \multirow{2}{*}{$\begin{array}{c}\text { Uranium } \\
\text { Concentration, } \\
\text { g per liter }\end{array}$} & \multirow[b]{2}{*}{$\begin{array}{c}\text { Normality of } \\
\text { Free Nitric Acid }\end{array}$} & \multicolumn{11}{|c|}{ Corrosion Rate, mils per month, After Indicated $96-\mathrm{Hr}$ Test Period } \\
\hline & & & First & Second & Third & Fourth & Fifth & Sixth & Seventh & Eighth & Ninth & Tenth & $\begin{array}{c}\text { Average of } \\
\text { First Four Periods }\end{array}$ \\
\hline Welded & 157. & $0.3^{(a)}$ & 0.20 & 0.15 & 0.17 & 0.13 & 0.17 & 0.21 & 0.17 & 0.19 & 0.17 & 0.20 & 0.16 \\
\hline Unwelded & 157. & 0.3 & 0.12 & 0.15 & 0.12 & 0.14 & 0.21 & 0.19 & 0.16 & 0.20 & 0.18 & 0.21 & 0.13 \\
\hline Welded & 157. & 3.0 & 1.58 & 1.66 & 1. 73 & 1. 71 & 1.91 & 1. 76 & 1.98 & 1. 81 & 1. 71 & 1.85 & 1.67 \\
\hline Unwelded & 157. & 3.0 & 1.54 & 1. 78 & 1.80 & 1.68 & 1.87 & 1.88 & 1.87 & 1.96 & 1. 89 & 1.92 & 1. 70 \\
\hline Welded & 157. & 6.0 & 3.07 & 3.47 & 3.84 & 3.69 & 3.91 & 4. 48 & 4. 26 & 4.00 & 4.55 & 3.91 & 3.52 \\
\hline Unwelded & 157. & 6.0 & 3.23 & 3.56 & 3.86 & 4.25 & 3.76 & 4.25 & 4. 48 & 4.61 & 4. 23 & 3.84 & 3.73 \\
\hline Welded & 157. & 9.1 & 4. 70 & 2.03 & 4. 41 & 15.02 & 19.8 & 16.7 & 18.9 & 38.0 & 20.5 & 6.98 & 11.12 \\
\hline Unwelded & 157. & 9.1 & 8.58 & $41.3^{(b)}$ & $51.2(b)$ & 9.66 & 9.55 & 13.1 & 10.1 & 8.45 & 7.98 & 7.26 & 9.12 \\
\hline Welded & 138. & 3.0 & 1. 01 & 1. 40 & 1.38 & 1.53 & 1.69 & 1. 61 & 1.53 & 1.65 & 1. 72 & 1.66 & 1.33 \\
\hline Unwelded & 138. & 3.0 & 1.06 & 1. 43 & 1.53 & 1.64 & 1.97 & 1.88 & 1.78 & 1. 76 & 1. 79 & 1. 77 & 1. 42 \\
\hline Welded & 106. & 6.0 & 1.89 & 2.48 & 2.57 & 2.96 & 3.38 & 3.07 & 2.90 & 3.41 & 3.68 & 3.43 & 2.48 \\
\hline Unwelded & 106. & 6.0 & 1.99 & 2.54 & 2. 79 & 2.96 & 3.53 & 3.15 & 3.05 & 3.22 & 3.33 & 3.37 & 2.57 \\
\hline Welded & 73.6 & 9.1 & 3.00 & 3.87 & 4.31 & 9.46 & 6.46 & 7.26 & 4.53 & 5.77 & 5.40 & 5.07 & 5.16 \\
\hline Unwelded & 73.6 & 9.1 & 3.25 & 4.14 & 6.08 & $52.2^{(b)}$ & 46.2 & 31.8 & 5.66 & 4.80 & 5.13 & 4.62 & 4. 49 \\
\hline
\end{tabular}

(a) As-received digest liquor.

(b) Data not included in determination of average. 


\section{$\mathrm{A}-2$}

TABLE A-2. THE EFFECT OF FREE NITRIC ACID ON THE CORROSION OF TYPE 347 STAINLESS STEEL BY REFERENCE 80 AND REFERENCE 250 LIQUORS

Samples Exposed in the Liquid Phase

\begin{tabular}{|c|c|c|c|c|c|c|c|}
\hline \multirow{2}{*}{$\begin{array}{l}\text { Specimen } \\
\text { Type }\end{array}$} & \multirow{2}{*}{$\begin{array}{c}\text { Uranium } \\
\text { Concentration, } \\
\text { g per liter }\end{array}$} & \multirow{2}{*}{$\begin{array}{l}\text { Normality } \\
\text { of Free } \\
\text { Nitric Acid }\end{array}$} & \multicolumn{5}{|c|}{$\begin{array}{l}\text { Corrosion Rate, mils per month, After } \\
\text { Indicated } 96-\mathrm{Hr} \text { Test Period }\end{array}$} \\
\hline & & & First & Second & Third & Fourth & Average \\
\hline Welded & 80 & 1 & 0.26 & 0.27 & 0.29 & 0.30 & 0.28 \\
\hline Unwelded & 80 & 1 & 0.25 & 0.29 & 0.30 & 0.30 & 0.29 \\
\hline Welded & 80 & $6^{(a)}$ & 1. 40 & 1.57 & 1.58 & 1.76 & 1.58 \\
\hline Unwelded & 80 & 6 & 1. 40 & 1.50 & 1.52 & 1.67 & 1.52 \\
\hline Welded & 250 & $1^{(b)}$ & 0.52 & 0.50 & 0.52 & 0.55 & 0.52 \\
\hline Unwelded & 250 & 1 & 0.53 & 0.54 & 0.56 & 0.58 & 0.55 \\
\hline Welded & 250 & 6 & 1. 52 & 1.80 & 1.86 & 2.11 & 1.82 \\
\hline Unwelded & 250 & 6 & 1.70 & 1.79 & 1.88 & 1.99 & 1.84 \\
\hline
\end{tabular}

(a) Reference 80 liquor.

(b) Reference 250 liquor. 
TABLE A-3. DATA INDICATING THE EFFECT OF FLUORIDE ADDITIONS TO REFERENCE 80 LIQUOR ON THE CORROSION OF TYPE 347 STAINLESS STEEL

\begin{tabular}{|c|c|c|c|c|c|c|c|}
\hline \multirow{3}{*}{$\begin{array}{l}\text { Total Fluoride } \\
\text { Present, } \\
\text { g per liter }\end{array}$} & \multirow{3}{*}{$\begin{array}{l}96-\mathrm{Hr} \\
\text { Test } \\
\text { Period }\end{array}$} & \multicolumn{6}{|c|}{ Corrosion Rate, mils per month } \\
\hline & & \multicolumn{2}{|c|}{$\begin{array}{l}\text { Specimens in } \\
\text { Vapor Phase } \\
\end{array}$} & \multicolumn{2}{|c|}{$\begin{array}{l}\text { Specimens at } \\
\text { Interface }\end{array}$} & \multicolumn{2}{|c|}{$\begin{array}{l}\text { Specimens in } \\
\text { Liquid Phase }\end{array}$} \\
\hline & & Welded & Unwelded & Welded & Unwelded & Welded & Unwelded \\
\hline \multirow[t]{3}{*}{0.097} & First & 0.32 & 0.33 & 1.05 & 0.95 & 1.37 & 1.33 \\
\hline & Second & 0.35 & 0.31 & 1. 24 & 1.04 & 1.57 & 1.63 \\
\hline & Average & 0.34 & 0.32 & 1.15 & 1.00 & 1.47 & 1.48 \\
\hline \multirow[t]{3}{*}{0.199} & First & 0.44 & 0.41 & 0.91 & 0.83 & 1.20 & 1.18 \\
\hline & Second & 0.47 & 0.37 & 1.15 & 1.04 & 1.53 & 1.77 \\
\hline & Average & 0.46 & 0.39 & 1.03 & 0.94 & 1.37 & 1.48 \\
\hline \multirow[t]{3}{*}{0.39} & First & 0.60 & 0.53 & 0.83 & 0.56 & 0.92 & 0.85 \\
\hline & Second & 0.61 & 0.62 & 0.97 & 0.76 & 1.21 & 1.07 \\
\hline & Average & 0.61 & 0.58 & 0.90 & 0.66 & 1.07 & 0.96 \\
\hline \multirow[t]{3}{*}{0.49} & First & 0.66 & 0.55 & 0.55 & 0.50 & 0.64 & 0.58 \\
\hline & Second & 0.54 & 0.63 & 0.70 & 0.61 & 1.02 & 0.82 \\
\hline & Average & 0.60 & 0.59 & 0.63 & 0.56 & 0.83 & 0.70 \\
\hline 0.97 & First $(a)$ & 2.94 & 4.28 & 3.83 & 2.82 & 3.19 & 2.98 \\
\hline 1.94 & First $(a)$ & 8.72 & 6.80 & 6.37 & 3.55 & 3.86 & 3.65 \\
\hline 4.85 & First $(a)$ & 18.30 & 15.40 & 18.20 & 9.38 & 10.50 & 8.36 \\
\hline \multirow[t]{3}{*}{9.7} & First & 7.10 & 7.30 & 35.18 & 12.82 & 33.40 & 16.50 \\
\hline & Second & 8.11 & 7.94 & 18.55 & 8.68 & 17.80 & 10.90 \\
\hline & Average & 7.61 & 7.62 & 26.87 & 10.75 & 25.60 & 13.70 \\
\hline
\end{tabular}

(a) One 36 -hr test period only. Localized attack at weld and heat-affected area. 
TABLE A-4. DATA INDICATING THE EFFECT OF FLUORIDE ADDITIONS TO REFERENCE 250 LIQUOR ON THE CORROSION OF TYPE 347 STAINLESS STEEL

\begin{tabular}{|c|c|c|c|c|c|c|c|}
\hline \multirow{3}{*}{$\begin{array}{c}\text { Total Fluoride } \\
\text { Present, } \\
\text { g per liter }\end{array}$} & \multirow{3}{*}{$\begin{array}{c}96-\mathrm{Hr} \\
\text { Test } \\
\text { Period }\end{array}$} & \multicolumn{6}{|c|}{ Corrosion Rate, mils per month } \\
\hline & & \multicolumn{2}{|c|}{$\begin{array}{l}\text { Specimens in } \\
\text { Vapor Phase }\end{array}$} & \multicolumn{2}{|c|}{$\begin{array}{l}\text { Specimens at } \\
\text { Interface }\end{array}$} & \multicolumn{2}{|c|}{$\begin{array}{l}\text { Specimens in } \\
\text { Liquid Phase }\end{array}$} \\
\hline & & Welded & Unwelded & Welded & Unwelded & Welded & Unwelded \\
\hline \multirow[t]{3}{*}{0.30} & First & 0.00 & 0.02 & 0.08 & 0.09 & 0.13 & 0.15 \\
\hline & Second & 0.00 & 0.01 & 0.06 & 0.06 & 0.14 & 0.18 \\
\hline & Average & 0.00 & 0.02 & 0.07 & 0.08 & 0.14 & 0.17 \\
\hline \multirow[t]{3}{*}{0.60} & First & 0.10 & 0.04 & 0.44 & 0.47 & 0.59 & 0.55 \\
\hline & Second & 0.07 & 0.05 & 0.43 & 0.41 & 0.61 & 0.62 \\
\hline & Average & 0.09 & 0.05 & 0.44 & 0.44 & 0.60 & 0.59 \\
\hline \multirow[t]{3}{*}{1.21} & First & 0.09 & 0.05 & 0.46 & 0.41 & 0.58 & 0.54 \\
\hline & Second & 0.09 & 0.06 & 0.46 & 0.40 & 0.64 & 0.62 \\
\hline & Average & 0.09 & 0.06 & 0.46 & 0.41 & 0.61 & 0.58 \\
\hline \multirow[t]{3}{*}{1.51} & First & 0.14 & 0.11 & 0.08 & 0.02 & 0.45 & 0.41 \\
\hline & Second & 0.14 & 0.11 & 0.43 & 0.33 & 0.39 & 0.35 \\
\hline & Average & 0.14 & 0.11 & 0.26 & 0.18 & 0.42 & 0.38 \\
\hline \multirow[t]{3}{*}{3.02} & First & 0.24 & 0.47 & 0.42 & 1.45 & 0.45 & 0.47 \\
\hline & Second & 0.28 & 0.25 & 0.20 & 0.23 & 0.39 & 0.40 \\
\hline & Average & 0.26 & 0.36 & 0.31 & 0.84 & 0.42 & 0.44 \\
\hline \multirow[t]{3}{*}{15.1} & First & 1.95 & 1.04 & 0.82 & 1.22 & 1.62 & 1.45 \\
\hline & Second & 1.44 & 0.86 & 1.16 & 0.83 & 1.11 & 1.10 \\
\hline & Average & 1.70 & 0.95 & 0.99 & 1.03 & 1.37 & 1.28 \\
\hline 30.2 & $\operatorname{First}(a)$ & 2.18 & 1.99 & 7.42 & 4.25 & 7.10 & 5.20 \\
\hline
\end{tabular}

(a) One 96-hr test period only. Localized attack at weld and heat-affected area. 


$$
\text { A-5 }
$$

TABLE A-5. DATA INDICATING THE EFFECT OF CHLORIDE ADDITIONS TO REFERENCE 80 LIQUOR ON THE CORROSION OF TYPE 347 STAINLESS STEEL

\begin{tabular}{|c|c|c|c|c|c|c|c|}
\hline \multirow{3}{*}{$\begin{array}{c}\text { Total Chloride } \\
\text { Present, } \\
\text { g per liter }\end{array}$} & \multirow{3}{*}{$\begin{array}{c}96-\mathrm{Hr} \\
\text { Test } \\
\text { Period }\end{array}$} & \multicolumn{6}{|c|}{ Corrosion Rate, mils per month } \\
\hline & & \multicolumn{2}{|c|}{$\begin{array}{l}\text { Specimens in } \\
\text { Vapor Phase }\end{array}$} & \multicolumn{2}{|c|}{$\begin{array}{l}\text { Specimens at } \\
\text { Interface }\end{array}$} & \multicolumn{2}{|c|}{$\begin{array}{l}\text { Specimens in } \\
\text { Liquid Phase }\end{array}$} \\
\hline & & Welded & Unwelded & Welded & Unwelded & Welded & Unwelded \\
\hline \multirow[t]{9}{*}{$0.056(a)$} & First & 0.41 & 0.36 & 1.42 & 1.17 & 1.40 & 1.40 \\
\hline & Second & 0.28 & 0.34 & 1.54 & 1.33 & 1.57 & 1.50 \\
\hline & Third & 0.41 & 0.39 & 1.79 & 1.40 & 1.58 & 1.52 \\
\hline & Fourth & 0.35 & 0.18 & 1.71 & 1.47 & 1.76 & 1.67 \\
\hline & Fifth & 0.33 & 0.38 & 1.72 & 1.42 & 1.75 & 1.61 \\
\hline & Sixth & 0.40 & 0.34 & 1.71 & 1.49 & 1.88 & 1.78 \\
\hline & Seventh & 0.29 & 0.19 & 1.28 & 1.02 & 1.14 & 1.07 \\
\hline & Eighth & 0.52 & 0.45 & 1.72 & 1.72 & 1.86 & 1.78 \\
\hline & $\begin{array}{l}\text { Average } \\
\text { of first } \\
\text { four }\end{array}$ & 0.36 & 0.34 & 1.62 & 1.34 & 1.58 & 1.52 \\
\hline \multirow[t]{11}{*}{0.11} & First & 0.52 & 0.51 & 1.46 & 1.41 & 1.60 & 1.50 \\
\hline & Second & 0.54 & 0.48 & 1.80 & 1.69 & 2.05 & 1.99 \\
\hline & Third & 0.43 & 0.36 & 1.89 & 1.79 & 1.82 & 1.77 \\
\hline & Fourth & 0.65 & 0.56 & 1.94 & 1.87 & 2.11 & 2.03 \\
\hline & Fifth & 0.52 & 0.46 & 1.50 & 1.35 & 1.74 & 1.70 \\
\hline & Sixth & 0.32 & 0.42 & 1.89 & 1.86 & 1.91 & 1.86 \\
\hline & Seventh & 0.57 & 0.52 & 1.84 & 1.82 & 1.85 & 1.79 \\
\hline & Eighth & 0.53 & 0.51 & 1.94 & 1.85 & 2.07 & 2.02 \\
\hline & Ninth & 0.59 & 0.51 & 1.93 & 1.90 & 2.00 & 1.89 \\
\hline & Tenth & 0.39 & 0.46 & 2.09 & 2.10 & 2.13 & 2.11 \\
\hline & $\begin{array}{l}\text { Average } \\
\text { of first } \\
\text { four }\end{array}$ & 0.54 & 0.48 & 1.77 & 1.69 & 1.90 & 1.82 \\
\hline \multirow[t]{9}{*}{0.22} & First & 0.42 & 0.31 & 1.29 & 1.19 & 1.27 & 1.37 \\
\hline & Second & 0.34 & 0.27 & 1.59 & 1.38 & 1.50 & 1.59 \\
\hline & Third & 0.47 & 0.42 & 1.40 & 1.29 & 1.47 & 1.54 \\
\hline & Fourth & 0.50 & 0.49 & 1.58 & 1.41 & 1.67 & 1.75 \\
\hline & Fifth & 0.46 & 0.23 & 1.50 & 1.30 & 1.55 & 1.66 \\
\hline & Sixth & 0.55 & 0.45 & 1.67 & 1.54 & 1.75 & 1.85 \\
\hline & Seventh & 0.34 & 0.28 & 1.10 & 1.00 & 1.04 & 1.11 \\
\hline & Eighth & 0.56 & 0.48 & 1.82 & 1.70 & 1.74 & 1.81 \\
\hline & $\begin{array}{l}\text { Average } \\
\text { of first } \\
\text { four }\end{array}$ & 0.43 & 0.37 & 1.47 & 1.32 & 1.48 & 1.56 \\
\hline \multirow[t]{5}{*}{0.56} & First & 0.58 & 0.39 & 0.89 & 0.90 & 1.43 & 1.21 \\
\hline & Second & 0.56 & 0.52 & 1.37 & 1.26 & 1.64 & 1.57 \\
\hline & Third & 0.49 & 0.44 & 1.32 & 1.18 & 1.47 & 1.40 \\
\hline & Fourth & 0.58 & 0.53 & 1.62 & 1.49 & 1.76 & 1.72 \\
\hline & Fifth & 0.49 & 0.45 & 1.35 & 1.21 & 1.65 & 1.59 \\
\hline
\end{tabular}




$$
\text { A-6 }
$$

TABLE A-5. (Continued)

\begin{tabular}{|c|c|c|c|c|c|c|c|}
\hline \multirow{3}{*}{$\begin{array}{c}\text { Total Chloride } \\
\text { Present, } \\
\text { g per liter }\end{array}$} & \multirow{3}{*}{$\begin{array}{l}\text { 96-Hr } \\
\text { Test } \\
\text { Period }\end{array}$} & \multicolumn{6}{|c|}{ Corrosion Rate, mils per month } \\
\hline & & \multicolumn{2}{|c|}{$\begin{array}{l}\text { Specimens in } \\
\text { Vapor Phase }\end{array}$} & \multicolumn{2}{|c|}{$\begin{array}{l}\text { Specimens at } \\
\text { Interface }\end{array}$} & \multicolumn{2}{|c|}{$\begin{array}{l}\text { Specimens in } \\
\text { Liquid Phase }\end{array}$} \\
\hline & & Welded & Unwelded & Welded & Unwelded & Welded & Unwelded \\
\hline \multirow{6}{*}{$\begin{array}{c}0.56 \\
\text { (continued) }\end{array}$} & Sixth & 0.59 & 0.63 & 1.67 & 1.61 & 1.89 & 1.84 \\
\hline & Seventh & 0.28 & 0.46 & 1.58 & 1.40 & 1.65 & 1.59 \\
\hline & Eighth & 0.61 & 0.57 & 1.94 & 1.74 & 2.01 & 1.94 \\
\hline & Ninth & 0.65 & 0.61 & 1.60 & 1.58 & 1.82 & 1.77 \\
\hline & Tenth & 0.61 & 0.60 & 1.68 & 1.56 & 1.84 & 1.75 \\
\hline & $\begin{array}{l}\text { Average } \\
\text { of first } \\
\text { four }\end{array}$ & 0.55 & 0.47 & 1.30 & 1.21 & 1.58 & 1.48 \\
\hline \multirow[t]{5}{*}{1.12} & First & 0.50 & 0.52 & 1.32 & 1.16 & 1.44 & 1.43 \\
\hline & Second & 0.49 & 0.46 & 1.46 & 1.26 & 1.54 & 1.48 \\
\hline & Third & 0.48 & 0.53 & 1.53 & 1.23 & 1.65 & 1.71 \\
\hline & Fourth & 0.52 & 0.51 & 1.49 & 1.22 & 1.61 & 1.58 \\
\hline & Average & 0.50 & 0.51 & 1.45 & 1.22 & 1.56 & 1.55 \\
\hline \multirow[t]{9}{*}{2.24} & First & 0.51 & 0.45 & 1.31 & 1.12 & 1.23 & 1.27 \\
\hline & Second & 0.42 & 0.42 & 1.36 & 1.10 & 1.24 & 1.25 \\
\hline & Third & 0.57 & 0.51 & 1.65 & 1.39 & 1.53 & 1.57 \\
\hline & Fourth & 0.57 & 0.53 & 1.49 & 1.03 & 1.35 & 1.42 \\
\hline & Fifth & 0.64 & 0.60 & 1.34 & 1.42 & 1.70 & 1.72 \\
\hline & Sixth & 0.62 & 0.60 & 1.22 & 1.33 & 1.55 & 1.60 \\
\hline & Seventh & 0.66 & 0.63 & 1.37 & 1.38 & 1.60 & 1.64 \\
\hline & Eighth & 0.66 & 0.62 & 1.56 & 1.62 & 1.78 & 1.83 \\
\hline & $\begin{array}{l}\text { Average } \\
\text { of first } \\
\text { four }\end{array}$ & 0.52 & 0.48 & 1.45 & 1.16 & 1.34 & 1.38 \\
\hline \multirow[t]{5}{*}{4.48} & First & 0.52 & 0.39 & 1.16 & 1.15 & 1.16 & 1.37 \\
\hline & Second & 0.50 & 0.47 & 1.16 & 1.10 & 1.23 & 1.30 \\
\hline & Third & 0.53 & 0.48 & 1.14 & 1.10 & 1. 24 & 1.19 \\
\hline & Fourth & 0.57 & 0.41 & 1.38 & 1.11 & 1.34 & 1.28 \\
\hline & Average & 0.53 & 0.44 & 1.21 & 1.12 & 1.24 & 1.29 \\
\hline \multirow[t]{5}{*}{8.96} & First & 0.48 & 0.54 & 1.11 & 1.14 & 1.08 & 1.45 \\
\hline & Second & 0.53 & 0.57 & 1.19 & 1.21 & 1.23 & 1.37 \\
\hline & Third & 0.61 & 0.43 & 1.16 & 1.15 & 1.19 & 1. 24 \\
\hline & Fourth & 0.46 & 0.35 & 1.29 & 1.16 & 1. 28 & 1.28 \\
\hline & Average & 0.52 & 0.47 & 1.19 & 1.17 & 1. 20 & 1.34 \\
\hline \multirow[t]{3}{*}{13.44} & First & 0.52 & 0.71 & 1.15 & 1.22 & 1.03 & 0.97 \\
\hline & Second & 0.47 & 0.66 & 1.06 & 1.15 & 1.10 & 1.01 \\
\hline & Average & 0.50 & 0.69 & 1.10 & 1.19 & 1.07 & 0.99 \\
\hline
\end{tabular}

(a) Initial calculated chloride concentration in Reference 80 liquor. 
TABLE A-6. DATA INDICATING THE EFFECT OF CHLORIDE ADDITIONS TO REFERENCE 250 LIQUOR ON THE CORROSION OF TYPE 347 STAINLESS STEEL

\begin{tabular}{|c|c|c|c|c|c|c|c|}
\hline \multirow{3}{*}{$\begin{array}{c}\text { Total Chloride } \\
\text { Present, } \\
\text { g per liter }\end{array}$} & \multirow{3}{*}{$\begin{array}{l}96-\mathrm{Hr} \\
\text { Test } \\
\text { Period }\end{array}$} & \multicolumn{6}{|c|}{ Corrosion Rate, mils per month } \\
\hline & & \multicolumn{2}{|c|}{$\begin{array}{l}\text { Specimens in } \\
\text { Vapor Phase } \\
\end{array}$} & \multicolumn{2}{|c|}{$\begin{array}{c}\text { Specimens at } \\
\text { Interface }\end{array}$} & \multicolumn{2}{|c|}{$\begin{array}{l}\text { Specimens in } \\
\text { Liquid Phase }\end{array}$} \\
\hline & & Welded & Unwelded & Welded & Unwelded & Welded & Unwelded \\
\hline \multirow[t]{9}{*}{$0.175(\mathrm{a})$} & First & 0.09 & 0.08 & 0.47 & 0.45 & 0.52 & 0.53 \\
\hline & Second & 0.06 & 0.08 & 0.40 & 0.45 & 0.50 & 0.54 \\
\hline & Third & 0.08 & 0.07 & 0.43 & 0.53 & 0.52 & 0.56 \\
\hline & Fourth & 0.03 & 0.08 & 0.57 & 0.45 & 0.55 & 0.58 \\
\hline & Fifth & 0.09 & 0.05 & 0.62 & 0.43 & 0.56 & 0.61 \\
\hline & Sixth & 0.10 & 0.07 & 0.52 & 0.55 & 0.83 & 0.62 \\
\hline & Seventh & 0.06 & 0.06 & 0.35 & 0.31 & 0.37 & 0.39 \\
\hline & Eighth & 0.12 & 0.09 & 0.61 & 0.55 & 0.63 & 0.68 \\
\hline & $\begin{array}{l}\text { Average } \\
\text { of first } \\
\text { four }\end{array}$ & 0.07 & 0.08 & 0.47 & 0.47 & 0.52 & 0.55 \\
\hline \multirow{11}{*}{0.35} & First & 0.10 & 0.10 & 0.51 & 0.49 & 0.55 & 0.51 \\
\hline & Second & 0.10 & 0.12 & 0.61 & 0.57 & 0.64 & 0.62 \\
\hline & Third & 0.07 & 0.11 & 0.55 & 0.59 & 0.61 & 0.59 \\
\hline & Fourth & 0.09 & 0.11 & 0.67 & 0.67 & 0.64 & 0.65 \\
\hline & Fifth & 0.08 & 0.09 & 0.60 & 0.58 & 0.60 & 0.60 \\
\hline & Sixth & 0.07 & 0.10 & 0.54 & 0.56 & 0.64 & 0.64 \\
\hline & Seventh & 0.08 & 0.09 & 0.64 & 0.55 & 0.63 & 0.63 \\
\hline & Eighth & 0.06 & 0.10 & 0.61 & 0.61 & 0.65 & 0.66 \\
\hline & Ninth & 0.07 & 0.11 & 0.56 & 0.55 & 0.68 & 0.69 \\
\hline & Tenth & 0.09 & 0.07 & 0.60 & 0.55 & 0.67 & 0.65 \\
\hline & $\begin{array}{l}\text { Average } \\
\text { of first } \\
\text { four }\end{array}$ & 0.09 & 0.11 & 0.59 & 0.58 & 0.61 & 0.59 \\
\hline \multirow[t]{10}{*}{0.70} & First & 0.05 & 0.08 & 0.54 & 0.52 & 0.50 & 0.56 \\
\hline & Second & 0.07 & 0.07 & 0.41 & 0.51 & 0.51 & 0.50 \\
\hline & Third & 0.05 & 0.10 & 0.53 & 0.50 & 0.55 & 0.55 \\
\hline & Fourth & 0.10 & 0.12 & 0.60 & 0.56 & 0.60 & 0.59 \\
\hline & Fifth & 0.05 & 0.07 & 0.56 & 0.54 & 0.63 & 0.59 \\
\hline & Sixth & 0.05 & 0.07 & 0.56 & 0.54 & 0.63 & 0.59 \\
\hline & Seventh & 0.09 & 0.08 & 0.62 & 0.59 & 0.62 & 0.64 \\
\hline & Eighth & 0.05 & 0.04 & 0.33 & 0.31 & 0.37 & 0.36 \\
\hline & Ninth & 0.07 & 0.09 & 0.58 & 0.52 & 0.62 & 0.61 \\
\hline & $\begin{array}{l}\text { Average } \\
\text { of first } \\
\text { four }\end{array}$ & 0.07 & 0.09 & 0.55 & 0.53 & 0.54 & 0.55 \\
\hline \multirow[t]{5}{*}{1.75} & First & 0.11 & 0.06 & 0.42 & 0.44 & 0.55 & 0.51 \\
\hline & Second & 0.11 & 0.10 & 0.56 & 0.50 & 0.64 & 0.63 \\
\hline & Third & 0.07 & 0.06 & 0.39 & 0.40 & 0.51 & 0.52 \\
\hline & Fourth & 0.10 & 0.08 & 0.43 & 0.45 & 0.60 & 0.61 \\
\hline & Fifth & 0.11 & 0.08 & 0.47 & 0.39 & 0.63 & 0.64 \\
\hline
\end{tabular}


TABLE A-6. (Continued)

\begin{tabular}{|c|c|c|c|c|c|c|c|}
\hline \multirow{3}{*}{$\begin{array}{c}\text { Total Chloride } \\
\text { Present, } \\
\text { g per liter }\end{array}$} & \multirow{3}{*}{$\begin{array}{l}96-\mathrm{Hr} \\
\text { Test } \\
\text { Period }\end{array}$} & \multicolumn{6}{|c|}{ Corrosion Rate, mils per month } \\
\hline & & \multicolumn{2}{|c|}{$\begin{array}{l}\text { Specimens in } \\
\text { Vapor Phase }\end{array}$} & \multicolumn{2}{|c|}{$\begin{array}{l}\text { Specimens at } \\
\text { Interface }\end{array}$} & \multicolumn{2}{|c|}{$\begin{array}{l}\text { Specimens in } \\
\text { Liquid Phase }\end{array}$} \\
\hline & & Welded & Unwelded & Welded & Unwelded & Welded & Unwelded \\
\hline \multirow{6}{*}{$\begin{array}{c}1.75 \\
\text { (Continued) }\end{array}$} & Sixth & 0.10 & 0.08 & 0.62 & 0.55 & 0.67 & 0.73 \\
\hline & Seventh & 0.09 & 0.08 & 0.51 & 0.52 & 0.67 & 0.67 \\
\hline & Eighth & 0.10 & 0.07 & 0.61 & 0.60 & 0.72 & 0.75 \\
\hline & Ninth & 0.10 & 0.09 & 0.64 & 0.64 & 0.73 & 0.73 \\
\hline & Tenth & 0.12 & 0.09 & 0.58 & 0.55 & 0.71 & 0.75 \\
\hline & $\begin{array}{l}\text { Average } \\
\text { of first } \\
\text { four }\end{array}$ & 0.09 & 0.08 & 0.45 & 0.45 & 0.58 & 0.57 \\
\hline \multirow[t]{5}{*}{3.5} & First & 0.12 & 0.12 & 0.58 & 0.57 & 0.76 & 0.77 \\
\hline & Second & 0.13 & 0.13 & 0.52 & 0.67 & 0.78 & 0.81 \\
\hline & Third & 0.11 & 0.04 & 0.63 & 0.68 & 0.88 & 0.92 \\
\hline & Fourth & 0.10 & 0.09 & 0.67 & 0.68 & 0.77 & 0.80 \\
\hline & Average & 0.11 & 0.10 & 0.60 & 0.65 & 0.80 & 0.83 \\
\hline \multirow[t]{10}{*}{7.0} & First & 0.15 & 0.13 & 0.76 & 0.73 & 0.95 & 0.93 \\
\hline & Second & 0.13 & 0.12 & 0.77 & 0.76 & 0.92 & 0.95 \\
\hline & Third & 0.10 & 0.14 & 0.88 & 0.95 & 1.15 & 1.18 \\
\hline & Fourth & 0.08 & 0.12 & 0.71 & 0.73 & 0.92 & 0.92 \\
\hline & Fifth & 0.13 & 0.14 & 0.83 & 0.82 & 1.13 & 1.14 \\
\hline & Sixth & 0.11 & 0.11 & 0.77 & 0.80 & 0.91 & 0.92 \\
\hline & Seventh & 0.14 & 0.14 & 1.04 & 0.85 & 1.04 & 1.07 \\
\hline & Eighth & 0.14 & 0.12 & 0.86 & 0.77 & 0.91 & 0.91 \\
\hline & Ninth & 0.10 & 0.24 & 0.96 & 0.91 & 1.06 & 1.08 \\
\hline & $\begin{array}{l}\text { Average } \\
\text { of first } \\
\text { four }\end{array}$ & 0.12 & 0.13 & 0.78 & 0.79 & 0.99 & 1.00 \\
\hline \multirow[t]{5}{*}{14.0} & First & 0.20 & 0.15 & 0.88 & 0.95 & 0.96 & 1.06 \\
\hline & Second & 0.22 & 0.14 & 1.06 & 0.95 & 1.17 & 1.25 \\
\hline & Third & 0.20 & 0.17 & 0.86 & 0.90 & 1.01 & 1.08 \\
\hline & Fourth & 0.21 & 0.16 & 1.04 & 0.98 & 1.14 & 1.15 \\
\hline & Average & 0.21 & 0.16 & 0.96 & 0.95 & 1.07 & 1. 14 \\
\hline \multirow[t]{5}{*}{28.} & First & 0.21 & 0.20 & 0.91 & 0.89 & 1.08 & 1.17 \\
\hline & Second & 0.18 & 0.19 & 0.97 & 0.97 & 1.23 & 1.22 \\
\hline & Third & 0.21 & 0.20 & 1.15 & 1.12 & 1.25 & 1.25 \\
\hline & Fourth & 0.20 & 0.20 & 1.06 & 1.17 & 1.31 & 1.25 \\
\hline & Average & 0.20 & 0.20 & 1.02 & 1.04 & 1.22 & 1.22 \\
\hline \multirow[t]{3}{*}{42.} & First & 0.49 & 0.37 & 1.29 & 1.24 & 1.22 & 1.32 \\
\hline & Second & 0.28 & 0.32 & 1.26 & 1.23 & 1.29 & 1.34 \\
\hline & Average & 0.39 & 0.35 & 1.28 & 1.24 & 1.26 & 1.33 \\
\hline
\end{tabular}

(a) Initial calculated chloride concentration in Reference 250 liquor. 
TABLE A-7. DATA INDICATING THE EFFECT OF ARSENATE ADDITIONS TO REFERENCE LIQUORS ON THE CORROSION OF TYPE 347 STAINLESS STEEL

\begin{tabular}{|c|c|c|c|c|c|c|c|}
\hline \multirow{3}{*}{$\begin{array}{c}\text { Total Arsenate } \\
\text { Present, } \\
\text { g per liter }\end{array}$} & \multirow{3}{*}{$\begin{array}{c}\text { 96-Hr } \\
\text { Test } \\
\text { Period }\end{array}$} & \multicolumn{6}{|c|}{ Corrosion Rate, mils per month } \\
\hline & & \multicolumn{2}{|c|}{$\begin{array}{l}\text { Specimens in } \\
\text { Vapor Phase }\end{array}$} & \multicolumn{2}{|c|}{$\begin{array}{l}\text { Specimens at } \\
\text { Interface }\end{array}$} & \multicolumn{2}{|c|}{$\begin{array}{l}\text { Specimens in } \\
\text { Liquid Phase }\end{array}$} \\
\hline & & Welded & Unwelded & Welded & Unwelded & Welded & Unwelded \\
\hline \multicolumn{8}{|c|}{ Reference 80 Liquor } \\
\hline \multirow[t]{5}{*}{$0.17^{(a)}$} & First & 0.32 & 0.30 & 1.1 & 0.99 & 1.2 & 1.2 \\
\hline & Second & 0.41 & 0.33 & 1.2 & 1.1 & 1.6 & 1.5 \\
\hline & Third & 0.39 & 0.30 & 1.3 & 1.1 & 1. 4 & 1. 3 \\
\hline & Fourth & 0.45 & 0.38 & 1.5 & 1.3 & 1.7 & 1.5 \\
\hline & Average & 0.39 & 0.33 & 1.3 & 1.1 & 1.5 & 1.39 \\
\hline \multirow[t]{6}{*}{0.80} & First & 0.54 & 0.42 & 1.3 & 1.1 & 1.4 & 1.3 \\
\hline & Second & 0.45 & 0.40 & 1.3 & 1.2 & 1.6 & 1.5 \\
\hline & Third & 0.49 & 0.41 & 1.4 & 1.2 & 1.5 & 1.4 \\
\hline & Fourth & 0.47 & 0.42 & 1.5 & 1.4 & 1.6 & 1.5 \\
\hline & Average & 0.49 & 0.41 & 1.4 & 1.2 & 1.5 & 1.44 \\
\hline & \multicolumn{5}{|c|}{ Reference 250 Liquor } & & \\
\hline \multirow[t]{5}{*}{0.054} & First & 0.09 & 0.05 & 0.44 & 0.47 & 0.51 & 0.54 \\
\hline & Second & 0.09 & 0.13 & 0.55 & 0.57 & 0.62 & 0.62 \\
\hline & Third & 0.10 & 0.07 & 0.59 & 0.45 & 0.59 & 0.62 \\
\hline & Fourth & 0.12 & 0.07 & 0.54 & 0.50 & 0.75 & 0.71 \\
\hline & Average & 0.10 & 0.08 & 0.53 & 0.50 & 0.62 & 0.62 \\
\hline \multirow[t]{5}{*}{2.5} & First & 0.10 & 0.08 & 0.58 & 0.48 & 0.61 & 0.54 \\
\hline & Second & 0.09 & 0.10 & 0.42 & 0.50 & 0.61 & 0.58 \\
\hline & Third & 0.09 & 0.08 & 0.55 & 0.49 & 0.57 & 0.58 \\
\hline & Fourth & 0.10 & 0.09 & 0.54 & 0.47 & 0.63 & 0.62 \\
\hline & Average & 0.10 & 0.09 & 0.52 & 0.49 & 0.61 & 0.58 \\
\hline
\end{tabular}

(a) Data for Reference 80 and 250 liquors with no additions and containing 0.009 and $0.027 \mathrm{~g}$ per liter arsenate are to be found at the head of Tables $A-5$ and $A-6$, respectively. 
TABLE A-8. DATA INDICATING THE EFFECT OF PHOSPHATE ADDITIONS TO REFERENCE LIQUORS ON THE CORROSION OF TYPE 347 STAINLESS STEEL

Specimens Exposed in the Liquid Phase(a)

\begin{tabular}{|c|c|c|c|}
\hline \multirow{3}{*}{$\begin{array}{c}\text { Total Phosphate } \\
\text { Present, } \\
\text { g per liter }\end{array}$} & \multirow{3}{*}{$\begin{array}{c}96-\mathrm{Hr} \text { Test } \\
\text { Period }\end{array}$} & \multirow{2}{*}{\multicolumn{2}{|c|}{ Corrosion Rate, mils per month }} \\
\hline & & & \\
\hline & & Welded & Unwelded \\
\hline \multicolumn{4}{|c|}{ Reference 80 Liquor } \\
\hline \multirow[t]{3}{*}{$1.46^{(b)}$} & First & 1. 27 & 1. 14 \\
\hline & Second & 1.45 & 1. 35 \\
\hline & Average & 1.36 & 1. 25 \\
\hline \multirow[t]{6}{*}{3.65} & First & 1. 18 & 1.13 \\
\hline & Second & 1. 22 & 1.23 \\
\hline & Third & 1. 25 & 1. 18 \\
\hline & Fourth & 1.37 & 1.36 \\
\hline & Average & 1. 26 & 1. 23 \\
\hline & Referenc & & \\
\hline \multirow[t]{3}{*}{4.58} & First & 0.53 & 0.56 \\
\hline & Second & 0.59 & 0.60 \\
\hline & Average & 0.56 & 0.58 \\
\hline \multirow[t]{5}{*}{11.45} & First & 0.53 & 0.57 \\
\hline & Second & 0.56 & 0.57 \\
\hline & Third & 0.58 & 0.60 \\
\hline & Fourth & 0.62 & 0.60 \\
\hline & Average & 0.57 & 0.59 \\
\hline
\end{tabular}

(a) Specimens in the vapor phase and at the interface exhibited slightly lower rates.

(b) Data for Reference 80 and 250 liquors with no additions and containing 0.73 and $2.3 \mathrm{~g}$ per liter phosphate are to be found at the head of Tables $A-5$ and $A-6$, respectively. 
TABLE A-9. DATA INDICATING THE EFFECT OF SULFATE ADDITIONS TO REFERENCE LIQUORS OF THE CORROSION OF TYPE 347 STAINLESS STEEL

\begin{tabular}{|c|c|c|c|c|c|c|c|}
\hline \multirow{3}{*}{$\begin{array}{l}\text { Total Sulfate } \\
\text { Present, } \\
\text { g per liter }\end{array}$} & \multirow{3}{*}{$\begin{array}{c}96-\mathrm{Hr} \\
\text { Test } \\
\text { Period }\end{array}$} & \multicolumn{6}{|c|}{ Corrosion Rate, mils per month } \\
\hline & & \multicolumn{2}{|c|}{$\begin{array}{l}\text { Specimens in } \\
\text { Vapor Phase }\end{array}$} & \multicolumn{2}{|c|}{$\begin{array}{l}\text { Specimens at } \\
\text { Interface }\end{array}$} & \multicolumn{2}{|c|}{$\begin{array}{l}\text { Specimens in } \\
\text { Liquid Phase }\end{array}$} \\
\hline & & Welded & Unwelded & Welded & Unwelded & Welded & Unwelded \\
\hline & & \multicolumn{3}{|c|}{ Reference 80 Liquor } & & & \\
\hline $36.6^{(a)}$ & First & - & - & - & - & 1.33 & 1.37 \\
\hline & Second & - & - & - & - & 1.37 & 1.50 \\
\hline & Third & - & - & - & - & 1.44 & 1.56 \\
\hline & Fourth & - & - & - & - & 1.51 & 2.02 \\
\hline & Fifth & - & - & - & - & 1.49 & 1.58 \\
\hline & $\begin{array}{l}\text { Average of } \\
\text { first four }\end{array}$ & - & - & - & - & 1.41 & 1.61 \\
\hline \multirow[t]{11}{*}{73.2} & First & 0.80 & 0.53 & 1.64 & 1.46 & 1.70 & 1.59 \\
\hline & Second & 0.86 & 0.62 & 1.48 & 1.60 & 1.80 & 1.69 \\
\hline & Third & 0.56 & 0.61 & 1.76 & 1.47 & 1.76 & 1.91 \\
\hline & Fourth & 0.80 & 0.66 & 1.89 & 1.77 & 1.91 & 1.84 \\
\hline & Fifth & 0.77 & 0.64 & 1.85 & 1.73 & 1.89 & 1.79 \\
\hline & Sixth & 0.62 & 0.83 & 2.13 & 1.94 & 2.12 & 2.03 \\
\hline & Seventh & 0.88 & 0.82 & 1.47 & 1.82 & 1.97 & 1.85 \\
\hline & Eighth & 1.10 & 0.99 & 2.35 & 2.14 & 2.23 & 2.13 \\
\hline & Ninth & 0.99 & 0.92 & 2.39 & 1.89 & 2.14 & 2.01 \\
\hline & Tenth & 0.95 & 0.78 & 2.10 & 1.90 & 2.13 & 2.00 \\
\hline & $\begin{array}{l}\text { Average of } \\
\text { first four }\end{array}$ & 0.76 & 0.61 & 1.69 & 1.58 & 1.79 & 1.76 \\
\hline \multirow[t]{5}{*}{100.} & First & - & - & - & - & 1.63 & 1.62 \\
\hline & Second & - & - & - & - & 1.75 & 1. 64 \\
\hline & Third & - & - & - & - & 1.78 & 1.80 \\
\hline & Fourth & - & - & - & - & 1.87 & 1.60 \\
\hline & Average & - & - & - & - & 1.76 & 1.67 \\
\hline \multicolumn{8}{|c|}{ Reference 250 Liquor } \\
\hline \multirow[t]{6}{*}{115.} & First & - & - & - & - & 0.91 & 0.89 \\
\hline & Second & - & - & - & - & 0.94 & 0.97 \\
\hline & Third & - & - & - & - & 1.00 & 0.99 \\
\hline & Fourth & - & - & - & - & 0.98 & 0.95 \\
\hline & Fifth & - & - & - & - & 0.99 & 0.75 \\
\hline & $\begin{array}{l}\text { Average of } \\
\text { first four }\end{array}$ & - & - & - & - & 0.96 & 0.95 \\
\hline
\end{tabular}




$$
\text { A- } 12
$$

TABLE A-9. (Continued)

\begin{tabular}{|c|c|c|c|c|c|c|c|}
\hline \multirow{3}{*}{$\begin{array}{l}\text { Total Sulfate } \\
\text { Present, } \\
\text { g per liter }\end{array}$} & \multirow{3}{*}{$\begin{array}{c}96-\mathrm{Hr} \\
\text { Test } \\
\text { Period }\end{array}$} & \multicolumn{6}{|c|}{ Corrosion Rate, mils per month } \\
\hline & & \multicolumn{2}{|c|}{$\begin{array}{l}\text { Specimens in } \\
\text { Vapor Phase } \\
\end{array}$} & \multicolumn{2}{|c|}{$\begin{array}{l}\text { Specimens at } \\
\text { Interface }\end{array}$} & \multicolumn{2}{|c|}{$\begin{array}{l}\text { Specimens in } \\
\text { Liquid Phase }\end{array}$} \\
\hline & & Welded & Unwelded & Welded & Unwelded & Welded & Unwelded \\
\hline \multirow[t]{11}{*}{230.} & First & 0.52 & 0.47 & 0.77 & 0.68 & 0.74 & 0.67 \\
\hline & Second & 0.39 & 0.42 & 1.23 & 1.11 & 1.81 & 1.54 \\
\hline & Third & 0.49 & 0.47 & 0.95 & 0.92 & 1.00 & 0.83 \\
\hline & Fourth & 0.22 & 0.39 & 1.34 & 1.44 & 1.90 & 1.74 \\
\hline & Fifth & 0.48 & 0.44 & 0.90 & 0.84 & 0.95 & 0.93 \\
\hline & Sixth & 0.45 & 0.47 & 1.56 & 1.38 & 2.06 & 2.02 \\
\hline & Seventh & 0.51 & 0.53 & 0.76 & 0.73 & 0.61 & 2.62 \\
\hline & Eighth & 0.49 & 0.52 & 1.83 & 1.60 & 2.20 & 2.06 \\
\hline & Ninth & 0.55 & 0.51 & 0.84 & 1.00 & 1.01 & 1.15 \\
\hline & Tenth & 0.44 & 0.53 & 0.92 & 1.40 & 1.31 & 1.45 \\
\hline & $\begin{array}{l}\text { Average of } \\
\text { first four }\end{array}$ & 0.41 & 0.44 & 1.07 & 1.04 & 1.36 & 1.20 \\
\hline
\end{tabular}

(a) Data for Reference 80 and 250 liquors with no additions and containing 18.3 and $57.3 \mathrm{~g}$ per liter sulfate are to be found at the head of Tables $A-5$ and $A-6$, respectively. 
TABLE A-10. DATA INDICATING THE EFFECT OF ABRASIVE ADDITIONS TO REFERENCE LIQUORS ON THE CORROSION OF TYPE 347

STAINLESS STEEL

Samples in the Liquid Phase

\begin{tabular}{|c|c|c|c|c|c|}
\hline \multirow{3}{*}{$\begin{array}{c}\text { Reference } \\
\text { Liquor }\end{array}$} & \multirow{3}{*}{$\begin{array}{c}\text { 96-Hr } \\
\text { Test } \\
\text { Period }\end{array}$} & \multicolumn{4}{|c|}{ Corrosion Rate, mils per month } \\
\hline & & \multicolumn{2}{|c|}{ Welded Specimens } & \multicolumn{2}{|c|}{ Unwelded Specimens } \\
\hline & & Sand Absent & Sand Present $(a)$ & Sand $\mathrm{Absent}$ & Sand Present \\
\hline \multirow[t]{5}{*}{ Reference 80} & First & $1.40^{\circ}$ & 1.52 & 1. 40 & 1.51 \\
\hline & Second & 1.57 & 1.87 & 1.50 & 2.01 \\
\hline & Third & 1. 58 & 1.62 & 1.52 & 2.08 \\
\hline & Fourth & 1.76 & 2.16 & 1.67 & 2.50 \\
\hline & Average & 1.58 & 1.79 & 1.52 & 2.03 \\
\hline \multirow{5}{*}{$\begin{array}{l}\text { Reference } 80 \text { plus } \\
3.65 \mathrm{~g} \text { per liter } \\
\text { total phosphate }\end{array}$} & First & 1. 18 & 1. 38 & 1.13 & 1. 37 \\
\hline & Second & 1. 22 & 1.51 & 1.23 & 1.70 \\
\hline & Third & 1. 25 & 1.44 & 1.18 & 1.65 \\
\hline & Fourth & 1. 37 & 1. 70 & 1. 36 & 1.99 \\
\hline & Average & 1.26 & 1.51 & 1.23 & 1.68 \\
\hline \multirow{5}{*}{$\begin{array}{l}\text { Reference } 250 \text { plus } \\
115 \mathrm{~g} \text { per liter } \\
\text { total sulfate }\end{array}$} & First & 0.91 & 0.61 & 0.89 & 0.63 \\
\hline & Second & 0.94 & 0.74 & 0.97 & 0.74 \\
\hline & Third & 1.00 & 0.79 & 0.99 & 0.77 \\
\hline & Fourth & 0.98 & 0.75 & 0.95 & 0.53 \\
\hline & Average & 0.96 & 0.72 & 0.95 & 0.67 \\
\hline
\end{tabular}

(a) 240 g per liter, minus 100 mesh silica sand added. This amount is approximately 2 lb per gal. 